\title{
Leveraging lessons learned to prevent future disasters-insights from the 2013 Colombia-US binational exchange
}

\author{
Carolyn Driedger ${ }^{1 *}$ D, Marta Calvache ${ }^{2}$, Gloria Patricia Cortés ${ }^{3}$, John Ewert ${ }^{4}$, Jacqueline Montoya ${ }^{5}$, Andy Lockhart ${ }^{4}$, \\ Robert Allen ${ }^{6}$, Daniel Banks ${ }^{7}$, Scott Beason ${ }^{8}$, Harold Trujillo Bocanegra ${ }^{9}$, Frances Burkhart ${ }^{10}$, Kyle Bustad $^{11}$, \\ Jaime Andres Gallego ${ }^{12}$, Zane Gibson ${ }^{13}$, Felix Ricardo Giraldo ${ }^{14}$, Cesar Gutierrez ${ }^{15}$, Jorge Ivan Quintero ${ }^{16}$, \\ Eduardo Rodríguez ${ }^{4}$, John Schelling ${ }^{17}$ and Marci Scott ${ }^{18}$
}

\begin{abstract}
In 2013, scientists implemented a binational exchange for emergency planners and responders in communities near Nevado del Ruiz in Colombia and volcanoes of the Cascade Range of the United States (US). This program was designed to promote understanding of volcanic disasters and effective mitigation options, motivate participants to strengthen emergency planning efforts, and promote trust-building among participants. The 2013 Binational Exchange was funded by the Volcano Disaster Assistance Program (VDAP), a joint U.S. Geological Survey (USGS)—U.S. Agency for International Development (USAID) program.

During a week-long visit to Colombian emergency response agencies, Nevado del Ruiz, and lahar-destroyed ruins of the city of Armero and the region of Viejo Rio Claro, US participants became familiar with Colombian counterparts who have had recent and frequent experiences addressing volcanic crises. Aging survivors and authorities of the Nevado del Ruiz catastrophe of 1985 gave participants first-hand accounts, and ideas for improved preparedness and response. While in the US, Colombian participants observed emergency response capabilities and facilities, and received training in systems of incident command. Colombians made presentations to the US public and officials about the similarities of lahar risks in both nations.

This article describes the 2013 Binational Exchange as an experiential learning event and uses results of post-exchange discussions and interviews as evidence of steps achieved within the learning process. Six years hence, this article provides examples of progress with volcano hazards mitigation in both nations. The article offers the binational exchange model as an effective tool that employs both experiential learning and socialization of participants to create a highly motivating and effective learning environment.
\end{abstract}

Keywords: Mount Rainier, Mount Baker, Nevado del Ruiz, Lahar, Mitigation, Education, Training, Emergency management, Experiential learning, Community-based disaster risk reduction (CBDRR)

\section{Introduction}

The case for 'long-term ongoing conversations' between scientists and officials

The groundwork for a disaster-resilient community requires that a whole community and its public officials be well informed about hazards, and capable of implementing risk-reduction measures (Paton et al. 2008;

\footnotetext{
* Correspondence: driedger@usgs.gov

'US Geological Survey-Cascades Volcano Observatory, 1300 SE Cardinal

Court, Vancouver, WA 98683, USA

Full list of author information is available at the end of the article
}

FEMA 2011a) For areas at risk from volcano hazards, the challenges for meeting these conditions are complex, and influenced by a broad assortment of socio-cultural factors, as well as exposure to previous experiences (Lane et al. 2003; Gregg et al. 2004; Chester 2005; Lavigne et al. 2008). This complexity is amplified in volcanic regions where eruption recurrence intervals are often lengthy, and public officials and people at risk have had minimal or no exposure.

Becoming well informed about hazards and effective protective measures requires pre-crisis trust-building 
among scientists and emergency officials and a complex web of stakeholders as noted by Mileti and Sorensen (1990); Mileti (1999); Barclay et al. (2008); Paton et al. (1999); Haynes et al. (2008a); Marzocchi et al. (2012); and more recently by Donovan and Oppenheimer (2016) and Becker et al. (2017). Mileti refers to the necessity of "long-term ongoing conversations" between scientists and stakeholders, which require two-way and long-term investment. On this issue, Fischhoff (1995) adds that the best hope for successful planning may come through a complex network of mutually respectful relationships. Numerous researchers have recognized that long-term trust, credibility, and community participation can be established through repeated informal interactions and formal demonstrations of agency commitment (Peters et al. 1997; Peterson 1988; GNS 1999; Newhall et al. 1999; Cronin et al. 2004a, 2004b; Ronan and Johnston (2005); Guffanti et al. 2006; Pierce County 2006; Peek et al. (2008); Haynes et al. 2008a and Haynes et al. 2008b; McGuire et al. 2009; and more recently in Donovan et al. 2014, Donovan and Oppenheimer 2016). This relationship building can facilitate response capabilities and identify areas for improvement (Paton and Jackson 2002; Doyle et al. 2015).

Scientists can assist residents by promoting acceptance of hazards information, apprising them of risk-reduction measures, and communicating information during extreme events (Peterson 1988; Newhall and Punongbayan 1996; Newhall et al. 1999; Cronin et al. 2004b; McGuire et al. 2009; Donovan et al. 2014; Pierson et al. 2014; Doyle et al. 2015; Becker et al. 2017). The term Whole Community Approach refers collectively to residents, emergency management practitioners, and leaders cooperatively assessing needs, seeking ways to strengthen their assets, capacities, and interests, and in doing so building societal security and resilience (FEMA 2011a; Sobelson et al. 2015).

Emergency officials bear much of the burden for coordinating emergency planning and response. Thus, there is irony in the fact that traditionally, fewer eruption mitigation trainings and learning products are directed to that audience than to scientists in the form of scientific literature and to geology students as classroom material. The history and breadth of materials for emergency officials is not known to be thoroughly documented, but there is suggestion that availability may be increasing. The twin set of videos about volcanic hazards and reducing risks (IAVCEI 1995, 1996) has been followed by VolFilm products (2019). The Tilling (1989) Short Course is followed by the FEMA Volcano Crisis Awareness course for officials (FEMA 2011b); by the USGS Volcano Volcanic Ash Impacts and Mitigation website (2019); and by the international volcanic ashhazard response posters for officials, assembled in New
Zealand (Wilson et al. 2014). With virtual certainty, smaller regional trainings for emergency officials exist in many nations, as exemplified by GNS (1999). Regardless of the availability and quality of hazards-mitigation information, when the student does not experience volcanic events, a vocabulary can be built without full understanding of meanings. Hence the value of experiential learning, as discussed below.

\section{The case for experiential learning}

In one of the twentieth century's fundamental conversations about effective education, theorists explored relative merits of educating through life experiences, contrasted with educating through systematic classroom education with a teacher as depositor of information. Theorists showed that people learn in transformative stages (Piaget 1952; Dewey 1958). In step with, or perhaps at the lead of twentieth-century cultural changes, the concept of experiential learning rose in favor and today its value is broadly acknowledged. The term experiential learning is defined as the process by which knowledge is created when a person is transformed by experience (Kolb et al. 2001; Kolb 2015). Working with foundations set by his predecessors, Kolb notes that learning progresses in recursive fashion through four cognitive stages: 1) encountering concrete experiences, 2) reflective observation, 3) abstract conceptualization, and 4) active experimentation. Reliance upon experiential learning to gain knowledge about effective eruption response can be problematic in some cases because of the infrequency of accessible eruptive events. This lack of experience can be partially overcome by frequent simulations and subsequent revision of preparedness plans. But, when people cannot visualize hazardous processes, they can be less able to identify and take required mitigation actions. In a paper examining factors that led to residents taking protective measures against eruption effects at Mount St. Helens, Perry and Lindell (1990) conclude that local officials must have: 1) a clear mental picture of eruption outcomes, and 2) knowledge of effective mitigation strategies, along with personal investment in successful mitigation outcomes. Perry and Greene (1983) noted that for emergency officials to be effective in applying information to disaster reduction, they must "see the problem and understand its consequences."

\section{Binational exchange offers opportunities for experiential learning}

Scientists at the United States Geological SurveyVolcano Disaster Assistance Program (USGS-VDAP) and the Servicio Geológico Colombiano (SGC) share a history of scientific mitigation work with an agreement administered through the US Agency for International 
Development (USGS-USAID). Communities in both nations share common threats, principally associated with lahars. Scientists reasoned that an exchange of emergency officials could be instructive and motivational. An intense and formal two-way venue could promote idea exchange, socialization, trust building, and motivation intra-nation as well as for inter-nation delegations. Travel to a disaster area that included conversations with original first responders and survivors could give officials valuable knowledge and the credibility back home as second-hand witnesses to eruption disaster and recovery. A binational exchange could provide opportunities for experiential learning.

This article describes the August-September 2013 Colombia-US Binational Exchange between emergency management officials near Mount Rainier (and one official from near Mount Baker) in the Cascade Range of the US, and their counterparts near Nevado del Ruiz in Colombia. We describe conditions prior to the 2013 exchange, implementation, and some results. We document methodologies used to capture participants' responses, evidence of learning, some lessons learned, and their application. The authors, all of whom were participants, demonstrate how an international exchange can afford opportunities for public officials to view firsthand the effects of lahars, observe mitigation and response strategies used by communities facing similar threats, and engage in discussions of cooperative planning within their home communities. The paper reveals the value of such an exchange as an educational and socializing tool, and its potential for application elsewhere.

This 2013 exchange was the first in a continuing series (binational exchanges to date are noted later in this article). We address the 2013 binational exchange alone because it was the first; it has been most documented and analyzed by participants; it was a catalyst for the funding of additional exchanges; and it provided evidence of the transformative value of international exchanges. This article provides an opportunity for binational exchange participants and their peers to reexamine the status of their efforts since the event. Readers considering organizing a binational exchange may find encouragement in the article.

\section{Background}

\section{Nevado del Ruiz}

Nevado del Ruiz is a broad glacier-capped stratovolcano located near the northern end of the Andes volcanic chain, approximately $100 \mathrm{~km}$ west of Bogota, Colombia (Fig. 1 and 2). The volcano rises ca. $5320 \mathrm{~m}$ above sea level and towers over the valleys of the Rio Magdalena on the east and the Rio Cauca to the west. Nevado del Ruiz is characterized by broad flanks with steep-walled canyons that are near vertical in some locations and

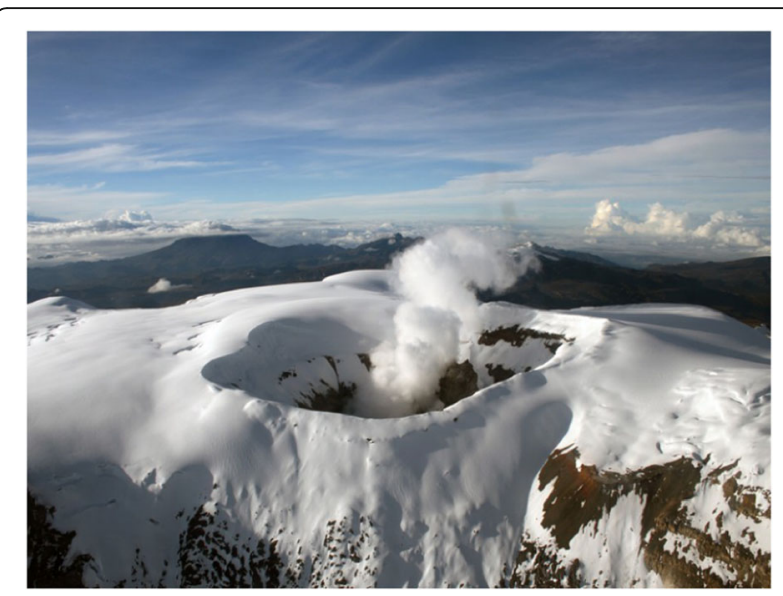

Fig. 1 Photo of Nevado del Ruiz from the north. On the evening of November 13, 1985, snow and ice on this summit ice cap melted and provided water for lahars. One formed on the northeast flank (Rio Azufrado) while a second originated on the Rio Lagunillas to the east. The two flows traveled down their respective valleys independently and joined. Around 11:30 pm the first lahar exited the mountain front and burst upon Armero, followed by a second surge. Photo by Milton Ordóñez Servicio Geológico Colombiano (SGC)

which are efficient conveyors of lahars. On the east side, the valleys extend approximately $60 \mathrm{~km}$ to a mountain front, where the rivers flow across alluvial fans that are the sites of towns and cities. On the volcano's northwest side, small communities exist within the narrow valleys. Historical records chronicle eruptions in 1595 and 1845 that killed more than 600 and 1000 people, respectively, at the site of the City of Armero (Siebert et al. 2010).

On the night of November 13, 1985, Nevado del Ruiz erupted and generated large lahars that swept down the valleys draining the summit area to the west, northeast, and east, resulting in more than 23,000 casualties (Voight 1990; Mileti et al. 1991; Hall et al. 1992) (Fig. 2). Observers and researchers reported details of events leading up to the eruption and lahars (Calvache 1990; Pierson et al. 1990), and the significant human factors that led to disasters at Armero and communities of the Chinchiná drainage (Voight 1990).

Lahars continue to threaten these communities that are now in part safeguarded by lahar detection systems, and by removal of people from the pre-1985 location of Armero. Approximately 50,000 to 80,000 people were at risk in drainages from the volcano during the 1985 event (Mileti et al. 1991) (Table 1).

\section{Cascade Range hazards}

In Washington State, five large glacier-clad volcanoes loom over densely populated lowland areas and are the sources of past and future lahars that pose risks similar to those at Nevado del Ruiz. Each Cascade Range volcano sustains glaciers that feed rivers in narrow valleys, 


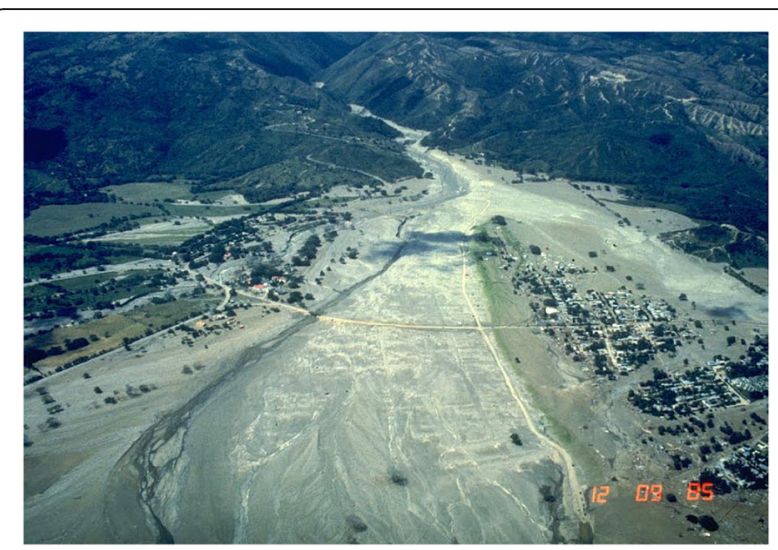

Fig. 2 Aerial photo of Armero, Colombia shows partial destruction caused by a lahar on November 13, 1985, that killed approximately 21,000 people at this site alone (see Pierson et al. 1990). Pattern of streets and building foundations are visible in the debris field at center of photo. USGS photo by R.J. Janda, 9 Dec 1985

which lead to large human population centers downstream. In Washington State, an estimated 191,555 residents, 108,719 employees at 8807 businesses, 433 public venues, and 354 dependent care facilities exist in lahar hazard zones (Diefenbach et al. 2015). Eruptions at all five volcanoes threaten both small and large human communities, industrial facilities, power infrastructure, agricultural producers, airspace, rail, road and river traffic, fish and wildlife habitats, and ultimately the regional economy of the nation's Pacific Northwest.

Mount Rainier (Fig. 3) is a $4392 \mathrm{~m}$-high stratovolcano formed during the past 500,000 years by the accumulation of countless lava flows and loose debris layers. Sisson and Vallance (2009) note the presence of ten to twelve eruptions during the past 2600 years. Central to its geological story is the development and continued presence of weak and collapse-prone hydrothermally altered rock, and glacier ice and perennial snow that during much of its history enveloped the volcano and which at present cover about $100 \mathrm{~km}^{2}$. The volcano's slopes are mantled by loose glacial-fluvial rock debris that can be remobilized quickly as it mixes with rainwater and snow and ice meltwater to make seasonal debris flows and eruption-related lahars. Five major glaciofluvial rivers commence at the termini of valley glaciers and they flow down narrow valleys to lowland areas that support large human populations.

During eruptions of the past 5600 years, lahars have traveled down most of Mount Rainier's steep-walled valleys, and spread over the flat valley floors $50 \mathrm{~km}$ or more from the volcano. These lahar deposits have been well documented as to source and age by examination of the rocks' provenance (Crandell 1971; Scott et al. 1992) and by the presence of tree stumps from forests buried and preserved by lahar debris (Pringle 2008). Mount Rainier is potentially one of the most hazardous volcanoes in the US (Hoblitt et al. 1998; Ewert et al. 2005). This designation is based upon knowledge of the volcano's eruptive style and frequency and the risks to people and infrastructure. More than 100,000 people and greater than $\$ 10 \mathrm{~B}$ of built property exist in the areas potentially subject to lahars (Cakir and Walsh 2012). Economic activity in the Seattle-Tacoma metropolitan area is also subject to volcanic ash fall (Wood and Soulard 2009a; Wood and Soulard 2009b) (Fig. 3). Some comparative factors are shown in Table 1.

\section{Conditions of volcano hazards preparedness leading into the 2013 binational exchange}

The 1985 Nevado del Ruiz incident had profoundly devastating consequences, but also later constructive effects within Colombia and international scientific and disaster management communities. At the national level, Colombia created a disaster preparedness and response system, the scope of which eventually was extended to encompass risk management at all levels of government (Vargas 2014). Colombia has trained its volcanologists, developed monitoring and warning systems, established communication with officials, and for over 30 years has implemented community education programs that have been used successfully in managing populations during volcano crises. The Colombian Geological Survey (SGC) is responsible for studying past and present activity of the nation's volcanoes. This responsibility now includes evaluating hazards, creating volcano hazard assessments and scenarios of activity, and monitoring and diagnosing volcanic activity (Fog 2015). These efforts were pioneered at the Volcanological and Seismological Observatory of Manizales (OVSM) and were later extended to two other

Table 1 Nevado del Ruiz and Mount Rainier comparative factors

\begin{tabular}{lll}
\hline Comparative factors & Nevado del Ruiz & Mount Rainier \\
\hline Snow and ice area & $\sim 10 \mathrm{~km}^{2}$ (Pierson et al. 1990) & $78.76 \mathrm{~km}^{2}$ (Beason 2017) \\
Distance down narrow valleys to population centers & $50 \mathrm{~km}$ (Pierson et al. 1990) & $60 \mathrm{~km}$ (Scott et al. 1992) \\
Most recent lahars & $1985 \mathrm{CE}$ & $1500 \mathrm{CE}$ \\
& $1845 \mathrm{CE}$ & 1000 years ago \\
& $1595 \mathrm{CE}$ & 2600 years ago \\
& & 5600 years ago \\
Current residents at risk in lahar-hazard zones & 100,000 at high risk (Thouret et al. 1990) & 91,435 (Diefenbach et al. 2015) \\
\hline
\end{tabular}



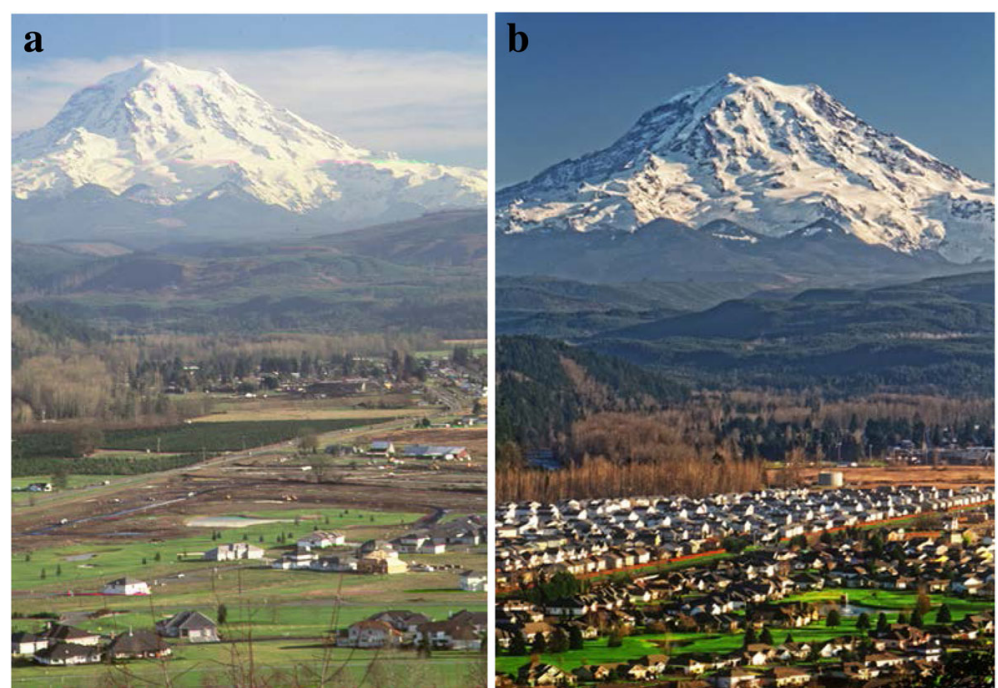

Fig. 3 a, b Photo of Mount Rainier with Puyallup valley in foreground in 1994 and 2014. On multiple occasions lahars flowed off the slopes of Mount Rainier to valleys as much as tens of $\mathrm{km}$ distant. A lack of land-use restrictions has allowed significant growth to continue on the valley floor that is at risk from future lahars. USGS photos 3a by David Wieprecht; 3b by E. Ruttledge

observatories at Pasto in 1980 and Popayán in 1993. Since 1985, Colombia has published volcano hazards assessments for 10 of 16 active volcanoes, installed hundreds of volcano monitoring stations, and developed a standardized alert activity level system and associated standard system for issuing information bulletins (Fog 2015). As of 2019 the nation supports monitoring 23 active volcanoes with 665 volcano monitoring stations. Worni et al. (2011) refers to evidence the death toll of lahars at Colombia's Nevado del Huila in 2007 and 2008 might have been higher if not for public education, installation of monitoring systems, and development of warning systems.

Despite this progress over thirty-plus years, Colombian volcanologists recognize that communication with the public and partners within the national system of risk management must move beyond the delivery of purely scientific results and provide meaningful information that can result in disaster prevention (Cortés 2011). Information about the volcanoes, hazards, and monitoring must be framed and socialized for the non-scientist (Fig. 4). The volcano observatories in Colombia approach the socialization (or social appropriation) of volcano knowledge (defined in Colombia as dissemination of hazard information) through a variety of approaches including observatory open houses, visits to schools, the Bienal Nacional de Niños, Niñas y Jóvenes que viven en zonas de riesgo volcánico, which is a biennial gathering for children and youth living in volcano hazard areas, talks and workshops, guided visits to the observatories, web page content, and a Facebook page, for example. With these activities, the volcano observatories are going beyond simply translating the science for the public and are developing professional relationships with communities, authorities, and news media. While much has been accomplished, there is long-term need to maintain public understanding and support for mitigation efforts.

In the US, the 1985 Nevado del Ruiz catastrophe in part prompted formation of the internationally focused USGS-USAID Volcano Disaster Assistance Program (VDAP). Domestically since the 1980s, volcano monitoring has advanced from the placement of isolated instruments to wholly integrated networks at more than a dozen volcanoes of the Cascade Range. They consist of approximately 75 seismometers and 60 GPS units within $16 \mathrm{kms}$ of each volcano. Beginning in the mid-1990s, the USGS Cascades Volcano Observatory updated volcano hazard assessments for Cascade Range volcanoes. Following the presentations of these hazard assessments, county officials and the Washington State Military Department's Emergency Management Division established long-term volcano hazard work groups to develop emergency coordination plans that address hazards at their respective volcanoes (Pierce County 2008). Each volcano hazard work group consists of emergency officials, community leaders, and scientists who develop, exercise, and maintain emergency coordination plans that employ the National Incident Management System (NIMS) for incident command (Homeland Security 2008), and who promote community risk-reduction measures.

Interest within the Mount Rainier volcano hazard work group prompted creation of the Living with a volcano in your backyard outreach program in 1995 that, while managed by USGS, is implemented with broad participation of local, state, and federal officials and concerned residents in areas at risk. This program began at 


\section{Activity levels}

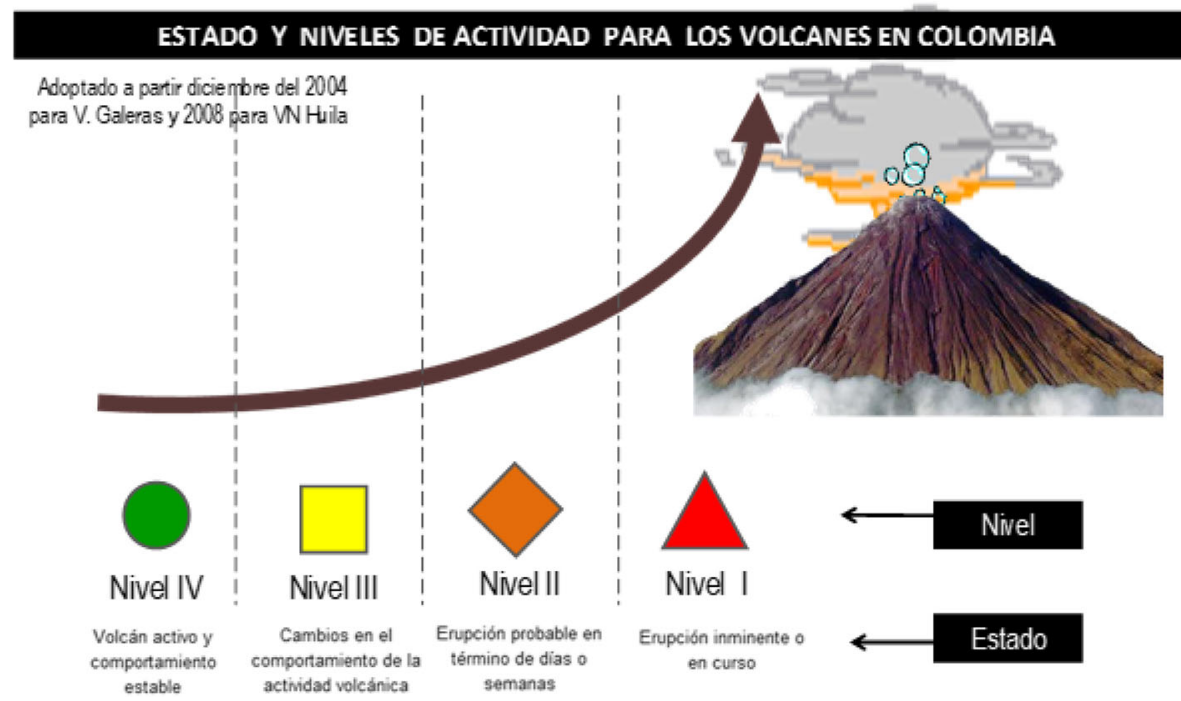

Fig. 4 Colombian scientists developed an activity level system and easy to understand graphics that describe conditions at Colombia's volcanoes. Servicio Geológico Colombiano (SGC)

the initiative of state and local officials and it follows general tenants of Community Based Disaster Risk Reduction (CBDRR) (Cadig et al. 2016). The goal is to encourage officials, individuals, and lahar-vulnerable populations to take responsibility for risk reduction within their communities through collaborative projects and services. Some examples include regular and occasional trainings with educational materials for the general public (Driedger et al. 1998), school educators
(Driedger et al. 2005; Myers and Driedger 2008a; Myers and Driedger 2008b), park interpreters (Driedger et al. 2002), and the news media (Driedger and Scott 2010). Some of this work is further analysed or described by Johnston et al. (2006), Cadig et al. (2016), Pierson et al. (2014), and Perry et al. (2016).

These products and services, planned and assembled with the active participation of stakeholders, can empower people to conduct mitigation activities (Paton

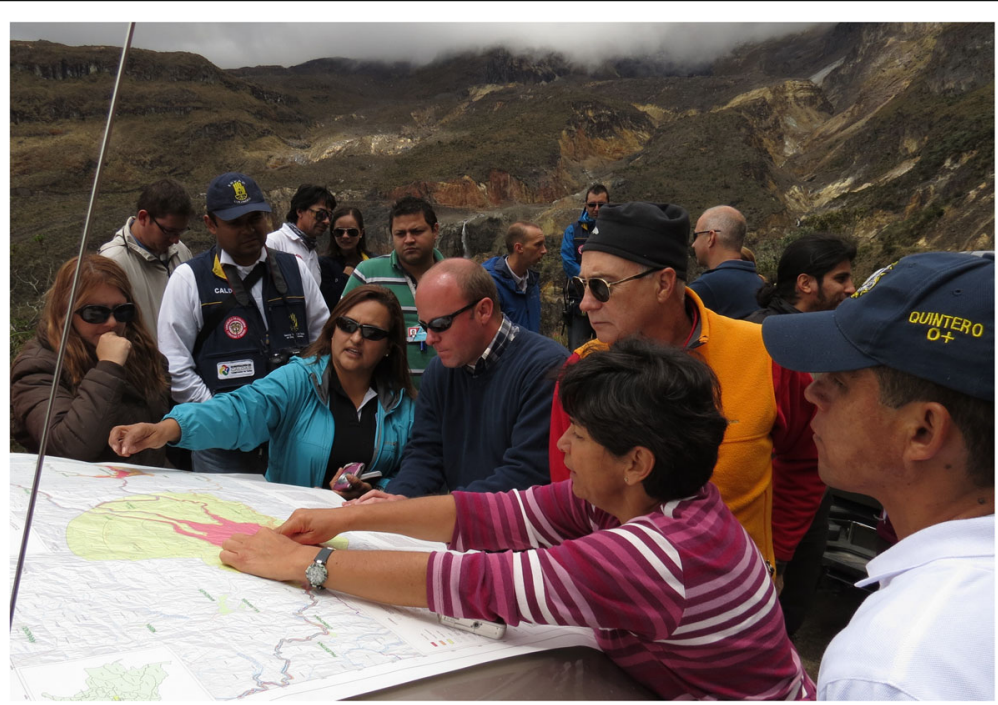

Fig. 5 Binational Exchange participants from Colombia and the US discuss source region of the 1985 lahar along the Rio Azufrado. USGS photo by C. Driedger August, 2013 
et al. 2008). In these endeavors, US scientists used the 1985 story of Nevado del Ruiz to illustrate the destructive power of lahars through the power of narrative as discussed by Dahlstrom (2014) and often with display of a single aerial photograph that shows part of the impacted city of Armero. (Fig. 2).

\section{Methods}

\section{Outline of the exchange}

During the spring of 2013, ten Colombians (nine traveled) and ten US participants were selected by SGC and USGS in consultation with lead emergency management officials to participate in the binational exchange, based upon their capacity to direct policy and programming within their agency. Most participants within each delegation had at least minor knowledge of each other. Some participants had aided in responses to eruptions at Mount St. Helens (1980) or Nevado del Ruiz (1985) and had prior knowledge and professional involvement in volcano mitigation efforts. Several participants had 'close calls' at previous volcanic events and had suffered personal losses, a fact that they attributed to increasing their motivation for fostering volcano risk reduction.

The binational exchange concept exists well within the larger mission of USAID/OFDA, which, amid other goals, is to produce humanitarian efforts to save lives (USAID 2019). Their funding of this binational exchange allowed concentrated learning opportunities that otherwise would not be readily available to local emergency officials of either nation. We show a list of agencies involved in the 2013 binational exchange in Table 2 . Tables 3 and 4 display trip itineraries respectively for US participants visiting Colombia (Fig. 5), and Colombian participants visiting the US (Fig. 6).

\section{Methods to establish effectiveness of the observations}

Participants were encouraged to document their trip by note taking, photos and video. Near the end of the trip and within several months thereafter, organizers used three types of interviews to record evidence of learning.

- Organizers arranged for a USGS media specialist to videotape one-on-one interviews of US and Colombian participants during the September binational exchange. Individuals were asked to speak generally about how the experience was important to them, most important lessons learned, mitigation methods that are tranferable between the volcanoes, and most meaningful aspects of the trip. Organizers transcribed much of the video.

- Organizers began one-on-one semi-structured interviews with US participants prior to their return to the US to collect first impressions and highlights of lessons learned. To aid this process, participants were asked to answer three questions: "What I Learned', 'How I plan to apply it", and 'Recommendations' to homebound colleagues. At end of the trip, most participants noted mental overload, and the need for reflection. In months following the exchange, input given in initial semi-structured interviews was returned in written form to each participant to be completed more thoroughly. This information

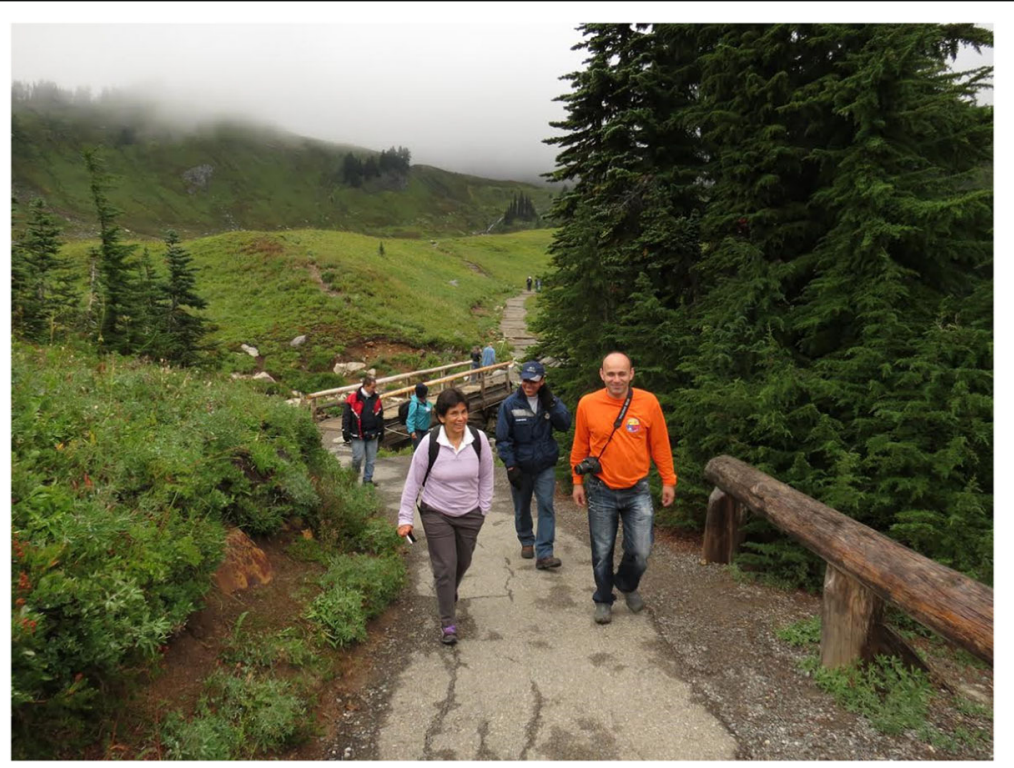

Fig. 6 Colombian visitors were guests at Mount Rainier National Park where they observed lahar deposits and exhibits intended to teach visitors about lahar hazards. USGS photo by C. Driedger, 2013 
Table 2 Home agencies of participants involved in the 2013 Colombia-US binational exchange trips

\begin{tabular}{ll}
\hline US agencies & Colombian agencies \\
\hline Mount Rainier National Park & $\begin{array}{l}\text { Bogota office of the US Office of Foreign Disaster Assistance } \\
\text { (OFDA) }\end{array}$ \\
$\begin{array}{l}\text { Orting Valley Fire and Rescue } \\
\text { Pierce County Department of Emergency Management (PCDEM) }\end{array}$ & $\begin{array}{l}\text { Environment and Risk Management of Tolima } \\
\text { Pierce County Economic Development Department (PCEDD) }\end{array}$ \\
$\begin{array}{l}\text { USAID Office of Foreign Disaster Assistance (OFDA) } \\
\text { USGS Volcano Science Center }\end{array}$ & Manizales Fire Department \\
$\begin{array}{l}\text { Washington State Military Department Emergency Management Division (EMD) } \\
\text { Washington State Health Department }\end{array}$ & Red Cross of Tolima \\
$\begin{array}{l}\text { Whatcom County Sheriff's Office Division of Emergency Management for the Department of Caldas } \\
\text { (WCSO-DEM) }\end{array}$ & Risk Management of Tolima \\
\hline
\end{tabular}

was assembled internally in table format for later analysis.

- Colombian organizers assembled all of their participants for a post-exchange structured discussion, asking the same questions verbally as with the US group. Their responses were recorded collectively (rather than individually) and referred to by each location visited within the US. This information was entered into table format similar to that developed for US participants.

- In a form of thematic analysis described by Maguire and Delahunt (2017), the information was analyzed for patterns and fitted into categories within Kolb's learning cycle. This entailed gaining initial familiarity with the content, coding by general themes, assigning one or more cognitive learning stages to participants' statements, and then listing statements thematically. Representative examples are included in this article.

\section{Results and discussion}

Within this section, Observations by participants provides evidence of learning using procedures described in Methods. Manifestations of the 2013 binational exchange explores longer-term manifestations of the 2013 binational exchange, both in Colombia and the US, and 2013 Binational Exchange inspires additional inter and intra-nation exchanges, which describes later venues.

Table 3 Itinerary for US travelers to Colombia, August 2013

\begin{tabular}{ll}
\hline Date & Visits \\
\hline Sunday August 25 & \\
Monday August 26 & $\begin{array}{l}\text { Visit to Bogota UNGRD and SGC; } \\
\text { Afternoon travel to Manizales }\end{array}$
\end{tabular}

Tuesday August 27

Visit agencies in Manizales region, and visit Chinchiná area, regional institutions, and OVSM in Manizales.

Wednesday August 28 Travel to Nevado del Ruiz

Thursday August 29 Travel to Armero New Armero/ Guayabal and ruins of Armero

Friday August $30 \quad$ Ibagué

Saturday August 31
Content

Arrival in Bogota.

US participants met with National, 'Departmental' (state), 'municipial' (county) and 'alcaldia' (city) disaster civil protection agencies with visits to SGC in Bogota. Officials described mechanisms for information sharing, and evacuation planning and exercising. They demonstrated the interoperability of protocols and systems. Participants observed interactions between scientists and civil protection agencies. They viewed a volcano-monitoring system, and learned about the history and hazards of Nevado del Ruiz, and the Colombian alert-level system.

Visit to Risk Management of Caldas (UDEGER) Civil Defense of Caldas that included a press conference. In towns of Chinchiná and Viejo Rio Claro that were damaged or destroyed by the 1985 Ruiz lahars, participants listened as survivors described disastrous lahar events and poignant personal losses. Visited Cruz Roja Colombiana - Seccional Caldas (Red Cross regional center); visited fire stations in Manizales and Villamaría. During observatory visit, learned about roles and capabilities of a volcano observatory at the Observatorio Vulcanológico y Sismológico de Manizales (OVSM).

Participants traveled to 5000 m elevation on Nevado del Ruiz to site of eruptiondestroyed El Refugio visitor facility; viewed high-elevation monitoring sites, and source areas of 1985 lahars.

Participants listened to eyewitness accounts from officials and residents of New Armero/Guayabal about 1985 lahar impacts; toured ruins of Armero. Visited fire station in New Armero/Guayabal.

Participants toured Environment and Risk Management of Tolima, including radio communications room. They visited officials present during 1985 lahar disaster. 
Table 4 Itinerary for Colombian travelers to the US, September 2013

\begin{tabular}{lll}
\hline Date & Visits & Content \\
\hline Sunday & Arrival in Portland, Oregon \\
Sept 15 & & \\
Monday & Visits to USGS Cascades Volcano Observatory; Mount St. Helens & Participants received an overview of US volcanoes and USGS Volcano \\
Sept 16 & National Volcanic Monument visitor facilities & Hazards Programming; Mount Rainier eruptive history and hazards; \\
& legacy of Mount St. Helens' 1980 catastrophic eruption; discussion of \\
& volcano tourist destinations as potentially useful platforms for volcano \\
& hazards interpretation.
\end{tabular}

Tuesday Visits to Pierce County Department of Emergency Management Sept 17 (PCDEM), visit to Red Cross, and Orting Valley Fire and Rescue
Thursday Trip to Mount Rainier National Park Sept 18

$\begin{array}{ll}\text { Friday } & \text { Trip to White River lahar deposits from } 5600 \text { year lahar originating } \\ \text { Sept } 19 & \begin{array}{l}\text { at Mount Rainier, and Mount Rainier National Park east side visitor } \\ \text { facilities }\end{array}\end{array}$

Sept 20 Visit Washington Emergency Management Division (EMD) at Camp Murray, WA
Discussion about the Mount Rainier lahar detection system, and about functions of the Emergency Operations Center (EOC), Mobile operations Center (MOC), facilities for Joint Information Center (JIC), and FEMA Urban Search and Rescue (USR). At Red Cross, learning about organizational functions and discussion of similarities and differences with Cruz Roja in Colombia. After a tour of Orting Valley Fire and Rescue, Dra. Marta Calvache briefed town council and fire commissioners about the 1985 Nevado del Ruiz experience. This prompted many informal discussions between local officials and binational exchange participants.

Discussion about the administration of a national park with volcano at center; the park and USGS partnership in support of improved monitoring; and staff and visitor safety concerning interpretation of Mount Rainier for visitors.

Visited Osceola lahar deposits along the White River and identified them as analog to deposits at Nevado del Ruiz; Dra. Marta Calvache made public evening presentation about lahar hazards.

Toured Emergency Operations Center (EOC) with overview of response section; and of lahar warning system terminal at EMD.

Sept 21 Departure to Colombia

\section{Observations by participants}

We list five themes that emerged from the US delegation and four themes expressed by the Colombians. Observational quotes chosen for inclusion are broadly representative of all observations cited by participants. Quotes originate from the semi-structured interview questions, and from video interviews. Parentheses indicate the relevance of specific observations to the four cognitive stages of experiential learning theory noted by Kolb et al. (2001) and Kolb (2015), as discussed further in the Introduction: 1) encountering concrete experiences, 2) reflective observation, 3) abstract conceptualization, and 4) active experimentation.

\section{US theme 1: the exchanges brought eye-opening realizations about lahar disaster realities}

The trip provided a new recognition of disaster realities, even for officials who previously had possessed textbook knowledge of the Nevado del Ruiz disaster. Kolb (2015) refers to a creative tension that is released as participants first grasp, then are transformed by the experience through the assimilation and distillation of information (concrete experience, abstract conceptualization, and reflective observation)

"Experiencing Armero, Viejo Rio Claro, and Chinchiná first-hand was completely different than what I had expected based on what I learned in Volcanology classes. It really opened my eyes to the reality of a crisis of this magnitude."

"We seem to think that this is an issue that only impacts a small area of Washington (State). People do not understand the infrastructure impacts that this will have and how long they will last."

Some learning led to comparisons with the volcanoes in the US, and intentions to act. (reflective observation, abstract conceptualization, active experimentation)

"When we went to Armero, something I'd seen and talked about, it really drove home the point of how similar the volcano of Mount Rainier is to the Nevado del Ruiz and the hazards that both volcanoes share. And it really opened my eyes to the things the Colombians had done that worked really well and continue to this day to work really well, and the ways that we can improve our emergency systems to make sure that the tragedies that happened in Armero in 1985 are not replicated here at Mount Rainier."

"The testimonials from the survivors made such an impact on me. As planners we try to plan for 
catastrophes though without ever experiencing the loss of hundreds, thousands of innocent people. This experience helps me ensure that the plans I create are actionable and something we can train and exercise to."

One participant expressed new perspective based upon reactions of visiting Colombians. (reflective observation, abstract conceptualization, active experimentation)

(During visits by Colombians to the US) "The Colombians were shocked and alarmed when they saw Orting. They were scared for us. We have adjusted to the threat and haven't had the human history impacts from an event like the Armero lahar to be scared."

"Life is going to be different after a (lahar) disaster."

US theme 2: there is great value in community preparation, including early childhood and lifelong learning about hazards and disaster reduction measures, and detailed planning for response

Numerous researchers acknowledge the value of including children in development of disaster reduction measures. Researchers at Vesuvius (Barberi et al. 2008; Carlino et al. 2008) address the need to educate school students as do Aspinall et al. (2002) at Montserrat, and Cardona (1997) in Colombia. During the Binational Exchange, New Armero (Armero Guayabal) then-mayor Mauricio Cuellar Arias, himself a survivor who as a boy lost many relatives during the 1985 lahar disaster, validated these studies when he stated the importance of early and lifelong education. Arias noted a basic lack of knowledge about the geographic connection between Armero and Nevado del Ruiz, adding that in school, children are introduced to great rivers of the world such as the Mississippi and Amazon. But he noted that they have not been taught about the connections that local rivers such as Rio Azufrado and Rio Lagunillas have to Nevado del Ruiz.

Participants saw evidence of post-1985 improvements in public knowledge of hazards as they asked questions of young children who followed the participants along a roadway in Viejo Rio Claro - Chinchiná. When asked about sirens situated around the town that are tested regularly, children noted that when the sirens sound, it means that a lahar is coming, that they should run up the hill, and that the sirens are not toys for play. (reflective observation and abstract conceptualization)

"Preparedness begins at an early age and the children we saw in Viejo Rio Claro Chinchiná knew EXACTLY what to do if the [lahar] alarm went off. All of the emergency planners in the country are determined to NEVER let what happened in 1985 happen again."

One US participant summed up the importance of lifelong education. (concrete experience, reflective observation and abstract conceptualization)

"The lack of information about volcano hazards begins in childhood with insufficient education about a community's connectedness to volcanoes. Later in life, and when volcano alerts are issued, this gap manifests as denial, and inability to move quickly due to limited understanding and motivation to take necessary actions that ensure survival."

Participants recognized the value of detailed planning and providing communities with detailed information for mitigation and recovery. (concrete experience, reflective observation and abstract conceptualization)

"[Need] dissemination of more specific what-to-do instructions."

"Appreciation for pre-identification of evacuation routes and emergency information hubs. Colombians include evacuation routes on some hazard maps. There is value in obtaining local input for identification of routes and hubs."

"Importance of telling people about the evacuation plan. During evacuations, there were incidents of cars striking pedestrians. Make evacuation plan so that cars don't conflict with evacuees on foot. At Ruiz they did not have antibiotics and blood plasma to aid survivors, and this caused many post-event fatalities."

"There is great value in scientists and emergency officials talking with local people about hazards and gaining their trust. A few dedicated individuals effected big changes (installation and regular testing of porch sirens, education of small children, evacuation routes identified and used in practice)."

One participant from the US expressed intention to ensure that his staff and their families are knowledgeable, and both personally and professionally prepared so that staff can dedicate time to their jobs knowing that their families are safe. (abstract conceptualization and active experimentation)

"The one thing that I took from this for me, is to make sure your employees are prepared and their families are prepared. And that is going to be my mission -- to make sure that [our] Fire and Rescue [group] is ready, prepared 
and have practiced our plan. And then we can pass that culture of preparedness down for generations to come."

\section{US theme 3: there is power in belief as well as knowledge that a disaster can happen}

Paton et al. (2008); Paton et al. (2010) discussed mental models with the required steps that lead from initial awareness to actions for preparedness. They further demonstrated the value of understanding the hazard and having a belief in the efficacy of hazards reduction and in their ability to apply it to their lives. This includes internalizing the message by first trusting the source; having belief in one's ability to take action, and belief that actions will be successful. One of the most memorable moments reported by participants occurred during a visit with a survivor near Chinchiná (El Pescador), who had lost many relatives during the 1985 disaster, including his mother. When asked about what message participants should bring back to people at risk from lahars in the US, he stated that we should believe that it can happen, identify a valid information source, and take action when told to do so. (reflective observation and abstract conceptualization)

\section{"Learned from survivors-Know your hazards. Know how to prepare for them. Know where to get reliable information. Act when needed-don't hesitate. BELIEVE it can happen."}

"The final thing that the survivors said is to believe it can happen and believe it can happen to you. Because if you can get to that point, the rest of the preparation will make sense, and you will do it."

In conversations among survivors and their relatives, traumatic memories of the 1985 disaster and the belief that it could happen again empower a psychological phenomenon known locally as the 'Ghost of Armero' that local authorities claim re-traumatizes, yet also motivates people to remain vigilant. (reflective observation and abstract conceptualization)

'The Ghost of Armero' serves as a powerful symbol for why they need to work together rather than at cross purposes."

\section{US theme 4: rebuilding community is more than fixing the infrastructure}

A US participant with an economic development background hypothesized that even if significant structural damage alone had caused impacts without loss of life, Armero still might not have survived as a vibrant community. Local inhabitants suggested to US participants that after the lahar, other communities were able to fill the economic role previously played by businesses in Armero. Once that substitution happened, the role was unlikely to have returned to the people who constituted the Armero business community, now devoid of the physical infrastructure they needed to operate.

Colombian hosts stated that after the 13 November 1985 lahar, some residents relocated to the north in nearby New Armero/Guayabal and other communities, but the disjointed global response to the tragedy contributed to fragmentation of the social community. With the physical infrastructure of the community gone, there was not a concerted and coordinated effort, at least not in the early days of the recovery, to relocate survivors in proximity to each other. Multiple organizations stepped in to help with relocation and rehousing. But efforts to build housing occurred whenever and wherever the opportunity arose, regardless of how those actions fragmented the relationships that constituted the community. The immediate need to shelter large numbers of people overruled considerations for the longer-term impacts on the community. (concrete experience and reflective observation)

\section{"Rebuilding community is much more than fixing the infrastructure. It's important to facilitate the reestablishment of relationships in a way that does not exacerbate problems that existed before the disaster."}

In their paper about creating hazard-resilient communities, Burby et al. (2000) identify land-use planning as the most promising approach for sustainable hazard mitigation and note the importance of hazards assessments and of crafting programs to manage urban development. Burby et al. (2000) note the broad scope of research suggesting that when local governments make the right choices in considering and implementing principles of land-use planning, communities are less likely to suffer severe losses of life and property during natural disasters. But, land use planning and zoning have their limits in an environment of strong property rights protection and economic imperatives, and where experience with the hazard is low (Perry and Lindell 2008). Even after disastrous events such as the Mount St. Helens eruption, some people want to accept the risks of living in general proximity to geologically dynamic areas (Perry and Greene 1983).

\section{US theme 5: strong interpersonal relationships, resident involvement in warning system maintenance, and cultural memories can contribute to effectiveness}

In Colombia, some residents play a personal role in lahar warnings by hosting government lahar warning sirens beneath house eaves and in community common areas, and by aiding with regular testing (Fig. 7). US participants inferred that the close personal interactions in 
Colombia enable a sense of societal connection and care. There was a general sense that experiencing warm personal relationships might balance out some advantages of more impersonal and complex technological warning systems used in the US. (concrete experience, reflective observation and abstract conceptualization)

"Colombians are more family and community oriented as a culture than we are, and that is reflected in their professional relationships. It allows them to have connections that span [mental] silos rather than reinforce them."

"Close personal ties within a community aid their ability to inform one another-more so than in the US with all our technologies."

\section{Observations by delegation from Colombia Colombian theme 1: a binational exchange invites comparison of risk reduction measures}

These comments demonstrate the ability of the binational exchange to deliver perspective to Colombian participants, who perhaps for the first time were able to compare their lahar detection and warning systems with analogs in other nations. (concrete experiences, reflective observation, abstract conceptualization)

"During our visit to Washington State, we were able to gain an appreciation for the advanced nature of the emergency response systems, protocols, and

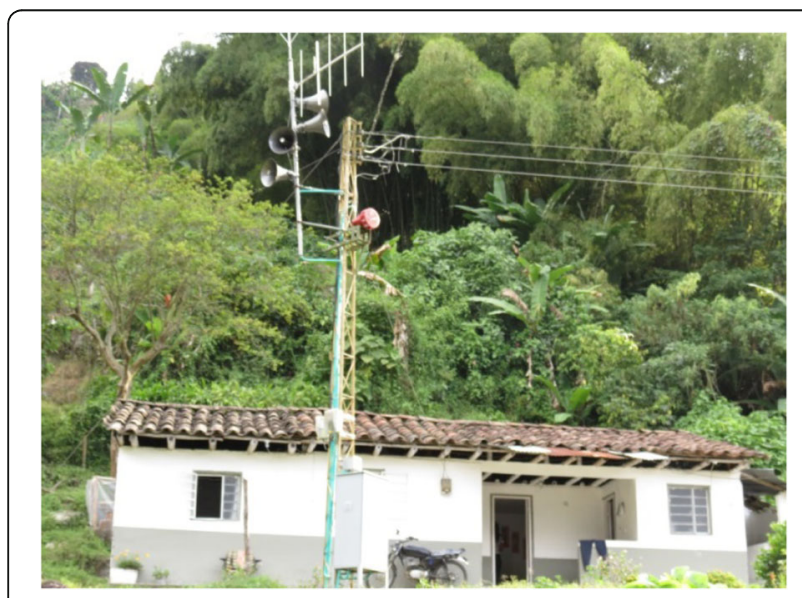

Fig. 7 In the upper center portion of the photo, a lahar siren system is visible mounted on a pole in the village of Viejo Rio Claro Chinchiná. Unlike in the US, local residents in Colombia have a personal role in lahar notification as they host and regularly test lahar siren devices installed beneath roof eaves and in public areas. USGS Photo by C. Driedger 2013 infrastructure that are available for emergency management in the Mount Rainier area."

"At Mount Rainier, we were particularly impressed with the evacuation routes and signage in valleys most at risk from lahars. We would like to adopt a similar evacuation route signage program at Nevado del Ruiz. Our US colleagues have shared the sign image with us so that we can adapt it for use in Colombia."

"At the same time, we were able to recognize and appreciate all the progress we have made in Colombia since 1985 in regards to volcano emergency management thanks to the support of the Colombian government and international assistance."

\section{Colombian theme 2: the binational exchange offered an opportunity to leverage participants' own experiences to help others}

There is potential for catharsis and motivational power in sharing pain, and perhaps the pain of disaster (Kearney 2008). These statements demonstrate a sense of validation for the intense efforts expended with post-1985 risk reduction efforts, and recognition that while survivors cannot bring back the people lost in 1985, the tragedy is useful for saving lives elsewhere. (concrete experiences, reflective observation, abstract conceptualization, and active experimentation)

"In seminars given to decision makers and the public, we emphasized the lessons we had learned about volcano disasters such as the 1985 eruption of Nevado del Ruiz, how we applied these lessons to the eruptions of Nevado del Huila in 2007 and 2008, and how volcanic eruptions do not need to be synonymous with volcanic disasters.

"I hope you can use us. The experience and the tragedy of Armero doesn't have to happen again, not in Colombia and not here, not in another place. And we have to learn from the bad experience of others. And we have to discuss and improve what we are planning to do and share those experiences."

"We can support each other. We are working and we know that we have a very large responsibility working in a volcano observatory but also you as a community, as a teacher, as an authority, as a decision-maker. You have your role, your responsibility in this community. So, we have to learn from each other. The volcano may erupt, but the tragedy doesn't have to happen. And that is the point." 
"As technicians we feel obligated to tell the decision makers that they must act in order to prevent catastrophes. In light of the experience we lived through in '85, we can tell you what an event of this nature is all about. It's solemn, delicate, complicated and human pain is transmitted to all the people who lose loved ones."

"It is a very important Binational Exchange due to the parallel geographical and physical similarities as well as the risk components of the surrounding areas of the volcanoes; we are learning from each other how to improve our capabilities so that we can protect the safety of the citizens in both regions."

"I believe, we must continue to share all our experiences and the knowledge of formal education in order to reduce risks in the event of a volcanic eruption anywhere in the world."

\section{Colombian theme 3: tourism and visitor facilities provide potential for volcano hazards education}

Colombian participants visited museum facilities at Mount Rainier National Park and Mount St. Helens National Volcanic Monument, which offer eyewitness accounts of eruptions, descriptions of geologic processes, evidence of past eruptions and current hazards, and guidance for safety. US park interpreters introduced participants to the Thematic Interpretation methodology. In this broadly accepted philosophy of park interpretation, exhibit information and face-to-face interpretation by professional park rangers provokes visitor thinking most effectively when it is thematic, organized, relevant, entertaining (TORE), and is presented as meaningful themes supported by select examples (Ham 1992; Ham 2013). There may be additional provocation to action when visitors respond to interpretation within established social groups such as families, friends, and classes. Comments about the importance of hazards-trained park staff also reinforce observations by Bird et al. (2010) in volcanic parks of Iceland, and policies promoting emergency response and communication training at Mount Rainier (Driedger et al. 2002), and at Mount St. Helens (Frenzen and Matarrese 2008; Driedger et al. 2008). Colombian participants perceived this as a model for use in Colombia. (concrete experiences, reflective observation, abstract conceptualization)

"At Mount St. Helens and Mount Rainier, we observed the great potential of tourism as a process for teaching visitors about the volcanoes and past volcanic events. From this experience we recognized the potential for interpretation centers near Nevado del Ruiz, which can help preserve the lessons learned in 1985 regarding risk management. These facilities can greatly improve the capabilities of our volcano hazards outreach program."

"Mt St. Helens and Mt Rainier are icons at state, national and international levels, and are seen as tourist and recreational places with economic uses, while the risks are recognized and are reported to visitors."

"Visitor Centers facilitate the interpretation of the messages of prevention and preparedness risk through design and teaching tools".

"At Mount St. Helens, I was impressed with the experience and professionalism of the Rangers to prevent risks to visitors."

\section{Colombian theme 4: we acknowledge cultural differences and common concerns}

Colombian participants made some broad statements about cultural differences and similarities, mainly in reference to societal customs. (concrete experiences, reflective observation)

"Your concerns are the same as ours and in this we are equals. But the ways in which we see things make us very different...[and]...it's the customs and the ways of life that makes us different, of course."

"And it's very important because it has allowed us to enter into the very similar realities of two far away countries, far away in distance only, because at the same time we are very close since we face similar situations as far as volcanoes are concerned. Therefore, we as volcanologists, as observatories and as fellow human beings are brought to work together towards the same goal."

\section{Manifestations of the 2013 binational exchange}

Manifestations of program effectiveness are addressed in two categories: Building of common understanding, relationships and trust, and Acceleration of progress on efforts for risk reduction.

Building of common understanding, relationships, and trust Trust built through common experience and relationship building has been cited as necessary for effective mitigation on multiple levels---between scientists and officials, officials and the public, and scientists and the public (Barclay et al. 2008; Haynes et al. 2008a, and 
Haynes et al. 2008b). In their study about fostering trust and credibility, Peters et al. (1997) provided evidence that public perceptions of governmental commitment can increase the sense of trust and credibility, as does perceived knowledge and expertise of citizen advocacy groups.

Proof of mutual common understanding and perhaps of trust exists 6 years after the 2013 binational exchange, as US scientists and officials resume conversations via email and telephone for discussion of volcanoes with familiarity and without introduction. Evidence of trust among officials exists in their ability to work together in volcano hazard work groups, and in their making frequent references to travel experiences. Indications of increased relationship building and commitment towards community members are evident from the approximately 40 presentations provided to audiences of residents at local libraries and community safety groups, and larger audiences at professional preparedness events between 2013 and 2018. In these presentations, participants conveyed their lessons learned in Colombia and spoke of similarities of hazards within the two nations. They also spoke to colleagues informally, at agency trainings, and at professional geoscience meetings, including at the 2014 Partnerships in Preparedness emergency management conference (Beason et al. 2014; Driedger et al. 2014; Driedger and Ewert 2015); and created a web-based video (Westby 2015). One example of improved perception of improved trust, commitment, concern, and care for at-risk residents is found in the community of Orting near Mount Rainier, where evacuation planning for many years had been accomplished independently, both by the school district and by emergency planners, but is now accomplished as a coordinated effort. Additionally, in order to promote an efficient evacuation of Orting, trusted partnerships built with officials in neighboring cities of Puyallup and Sumner now promote coordinated lahar evacuation plans across the region.

Multiple agencies have achieved a sense of trust and work in partnership on common outreach products and venues as noted in the section below. The public's current willingness to work as support personnel during evacuation drills, to promote new ideas for rapid community evacuation, and to host emergency managers in their homes for neighborhood meetings is evidence of a larger body of community expertise, knowledge, trust, and credibility.

One of the Colombians' long-term challenges has been to maintain long-term professional relationships between officials of different jurisdictions (departments that are akin to US states). The 2013 Binational Exchange included officials from the departments of Caldas and Tolima, which represent different flanks and lahar- prone valleys, and remote communities around Nevado del Ruiz. During the Binational Exchange, some Colombian travellers became acquainted with one another for the first time. The 2013 Binational Exchange trips in Colombia and the US strengthened relationships and mutual credibility among officials in Caldas and Tolima, and enabled more coherent mitigation efforts. These interactions have spread to communications with classroom teachers and the news media. Conversations during preparations for visiting participants from the US included community-based teachers, students, emergency response groups, mayors and other officials, and the news media. This broad approach has increased the number of trusted interactions among the above groups and strengthened their official communications through common purpose.

\section{Acceleration of progress in volcano risk reduction}

In post-Binational Exchange interviews, US participants expressed intentions to advance volcano mitigation within their respective professions. The Mount Rainier National Park geologist stated intentions to use the information from the Colombians' experiences to enhance staff safety training; to develop lahar evacuation routes in populated areas within the park; and to improve the park's capacity to respond safely to small seasonal debris flows. His efforts began immediately upon return from the Binational Exchange. To date, the park geologist has developed park lahar evacuation routes, referenced the Colombians' experiences repeatedly in park safety trainings and more broadly with professional geology colleagues; installed new stream gages on debris flow-prone rivers in the park; and developed a weather algorithm that identifies periods of enhanced likelihood of seasonal debris flows. He maintains attendance at multi-agency volcano hazard work group meetings that address updating and maintenance of emergency coordination plans, and professional involvement in the local fire department.

The economic development council staff member stated intentions to broaden the planning community's consideration of community planning measures that decrease damage and mortality during disasters, and improve the likelihoods for survival and rapid recovery. $\mathrm{He}$ facilitates relationship building between land-use planners and emergency managers as an ongoing and long-term professional responsibility. He has worked in support of more recent binational exchange events and attends some volcano-related planning meetings.

Emergency management participants collectively expressed intentions for greater inclusion of volcano hazards in emergency planning documents, and for more volcano hazards education for professional colleagues and the public. Within a year after their return, emergency managers developed public interpretive signs and 
webpages about volcanic hazards and preparedness for Mount Rainier, and soon after at Mount Baker and Glacier Peak (Schelling et al. 2014; Ekse et al. 2015) (Fig. 8). The Binational Exchange prompted additional invitations from officials to scientists to offer the FEMA Volcano Crisis Awareness (2011b) training in multiple communities, almost doubling the number of offerings given in the 3 years previous. Some participants now hold positions of greater responsibility than in 2013. One of the emergency management participants now oversees county operation of the Mount Rainier lahar notification system. Another emergency manager, who had been stationed at the State's health department, notes that the binational exchange broadened his understanding of effective eruption response. He oversaw the inclusion of lahar (mudflow) information on the health agency's website; his binational exchange presentation has been shown dozens of times to professional and public audiences. Now at the State Department of Transportation, he intends to include lahars within the agency's new catastrophe planning tools. Yet another 2013 participant now addresses all hazards at the Federal level. The Mount Baker focused emergency manager expressed intentions to ensure that volcanoes were incorporated in the Whatcom County Comprehensive Emergency Management Plan; that the Mount BakerGlacier Peak Coordination Plan was updated and exercised; and that volcano-specific public outreach and education was conducted. These tasks, and others related to volcano hazards mitigation have been accomplished.

Today, the fire chief draws a direct connection between the 2013 binational exchange and current coordinated plans for action within the fire department, with adjacent jurisdictions, and with school and city

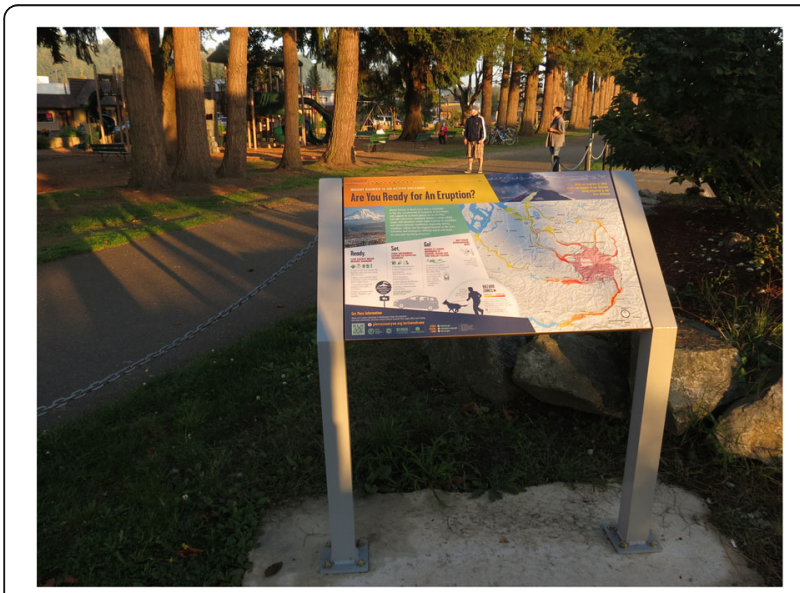

Fig. 8 This outdoor interpretive sign at Central Park in Orting, Washington was designed by some participants of the 2013 binational exchange and their agency colleagues. USGS photo by C. Driedger, October 10, 2014 government. He stated his intentions to write and exercise a lahar emergency Plan of Action, and then to develop a template of it for surrounding fire response jurisdictions. During the trip to Colombia, he recognized the extent of long-term engagement that would be required of his staff during a lahar emergency, and he proposed to encourage employees to make preparedness plans with their families. Additionally, he hoped for an informal sister status between fire departments in Manizales, Colombia and Orting, US. Since 2013, the fire chief has been promoting employee family preparedness; he has overseen development of a Plan of Action for Orting and coordinated development of similar plans with adjacent fire jurisdictions. The fire chief foresees a time when the Action Plan can be enacted automatically when a lahar is detected, and when the plan will include provision of aid from non-affected areas. While visiting Colombia, the fire chief was intrigued by the wellcoordinated multi-agency planning of lahar evacuation drills. In response to his 2013 observations, the fire chief has reached out to school administrators who had been conducting school district planned lahar evacuation drills since the late 1990s. Today, lahar evacuation drills in Orting are accomplished as a multi-agency effort with involvement of the school district, fire department, city government, and adjacent jurisdictions. In his postbinational exchange interview the fire chief noted the tragedies of car-pedestrian accidents in Amero during evacuation from the 1985 lahar. Currently, lahar evacuation routes in Orting are being adjusted to minimize potential car-pedestrian accidents during drills and actual evacuations.

The science agency outreach coordinator stated intentions to work with state and local agencies to improve coordination of state-wide volcano hazards awareness/ preparedness plans that could inform policy decisions to improve consistency of products and messaging; expansion of the volcano hazards product portfolio and information hubs for the public; and review of messages and operational plans. Professional connections developed through the Binational Exchange have promoted consistency in product styles and messaging. The outreach coordinator has worked in partnership with emergency management colleagues to update emergency preparedness plans with particular attention to updating and clarifying emergency communications plans. Overall, outreach coordination has benefited from new professional connections and from long-term involvement by 2013 Binational Exchange participants in volcano hazard risk reduction efforts.

For the Colombians, the 2013 visit to park interpretive facilities at Mount Rainier and Mount St. Helens inspired them to consider geoparks as platforms for teaching about volcano hazards and risk reduction, for 
memorializing previous volcanic disasters, and for strengthening connections between their observatories and park managers who regulate the placement of scientific monitoring devices. Colombian scientists and officials are pursuing the creation of a UNESCO Geopark at Nevado del Ruiz. Conversely, these visits reminded US park officials that the volcano over which they hold jurisdiction has societal relevance on many levels including its potential to impact nearby communities and urban areas.

Colombian scientists note that Nevado del Ruiz does not respect geographical borders or political boundaries. Between 25 and 29 August 2014, they held the first "Intercambio Regional Nevado del Ruiz: Departamentos de Caldas y Tolima" during which field visits to both sides of the volcano provided opportunities to discuss the hazards, mutual systems of communication, and how they could improve coordination among scientists, decision makers, emergency managers, and the public. Like the 2013 Binational Exchange, this regional exchange involved personnel from regional and municipal governments, the Red Cross, fire departments, and the national park, among others.

During the 2013 Binational Exchange, New Armero/ Guayabal mayor Mauricio Cuellar Arias and others expressed a hope that memorialization and tourism at Armero would develop beyond tours of the ruins. $\mathrm{He}$ foresaw tourism as a reminder to future generations about the past and as a motivator for preparedness, as well as a way to boost local revenues. Around 2013, he initiated development of a new museum and park dedicated to the memory of the approximately 23,000 or more people lost during the 1985 lahar disaster and to the need for long-term risk mitigation. This city block-sized park is named the Omaira Sánchez Memorial Park, in memory of the 13-year old girl who perished from entanglement in mud and debris. Later, the Mayor dedicated the museum and surrounding park, with a statue of Omaira Sánchez that reminds visitors of the courage of that small girl and of her community. In 2018, the SGC developed state-of-the art exhibits there, which illustrate Nevado del Ruiz hazards, types of volcanic phenomena, and monitoring devices (Fig. 9). The Armero House exhibit narrates the history of "avalanches" (lahars). It tells the story of the city and its people before, during and after the disaster of November 1985. Within it, the SGC presents the Nevado del Ruiz hazard map and a photographic exhibition that illustrates the volcanic risk in the region. In December 2018, the Omaira Sánchez Memorial Park was placed under the administration of a state-run organization to ensure its continuance. Several $\mathrm{kms}$ away at the ruins of
Armero, staff at the new Centro de Visitantes de Armero (CVA) help visitors to understand the tragedy.

Local artist and organizer Hernán Dario Nova, is creating a series of stele monuments, each one depicting the ambience of a former neighborhood within Armero. Near the center of the old city, where in 1985 Pope John Paul comforted people in the wake of the disaster, this artist also has created a memorial containing 25,000 small stones in commemoration of lost souls, with hopes of keeping the families of Armero alive in memory.

When all of these relatively recent advances in memorialization are considered, an important realization emerges, which is yet to be proven. The first generation of survivors and eyewitnesses who had personal losses as children, now as adults, possess personal motivation and are in positions of power to set policy and establish venues for disaster memorialization, hazard mitigation, and education. One might wonder if, after this generation has passed, the potential for mitigation policies and memorialization will decline. Hopefully not, if efforts such as the 2013 Binational Exchange are truly and fully successful.

\section{The 2013 binational exchange inspires additional inter and intra-nation exchanges}

Successes of the 2013 Mount Rainier/Nevado del Ruiz Binational Exchange provided broad momentum and served as a catalyst for funding of later mostly smaller, thematic binational exchanges. While some were unrelated to the concerns of the 2013 binational exchange, overlap particularly with the 2017 binational exchange likely reinforced momentum of the 2013 binational exchange.

\section{Commemorating the 2015 30th anniversary of the Nevado del Ruiz eruption}

Four US scientists and one county-level emergency manager visited Colombia to observe commemorations in Caldas and Tolima, to attend the preliminary opening of a Nevado del Ruiz-focused museum alluded to in 2013, and to demonstrate international support for mitigation efforts.

\section{Sharing educational resources}

An April 2016 trip took five US participants to Colombia and introduced staff members from volcano parks and emergency management in the US to their counterparts in Colombia. In July 2016, two visiting Colombian classroom educators and two observatory-based educators joined US participants at the Mount RainierLiving with a volcano in your backyard teacher workshop to explore options for modifying US classroom 


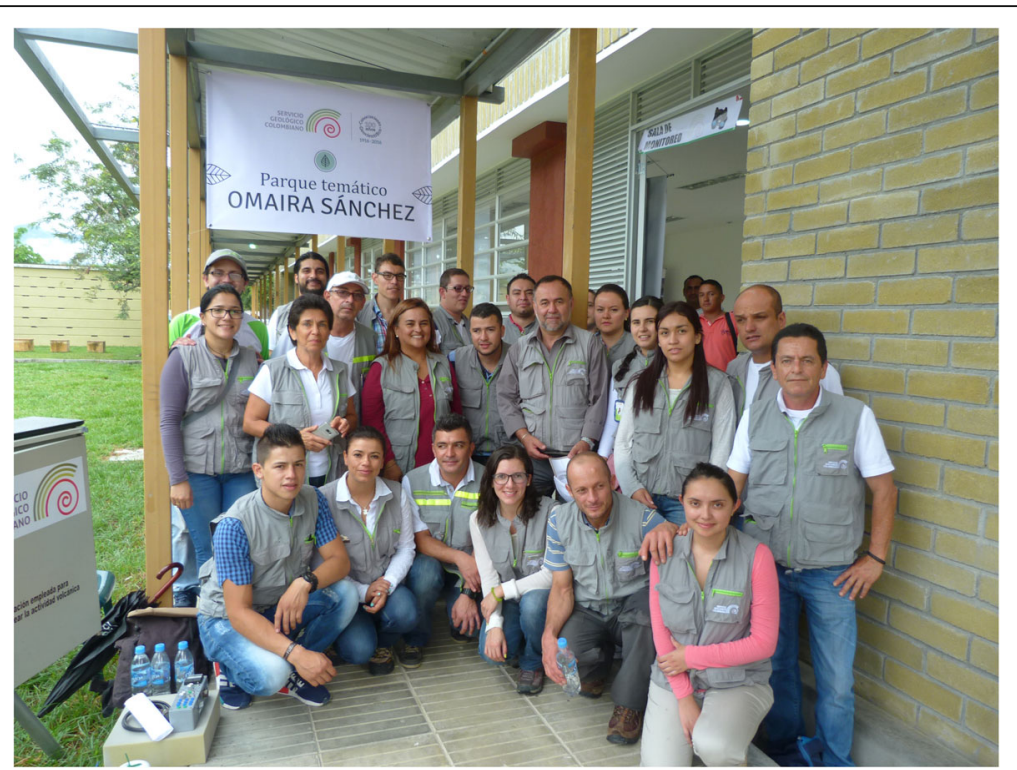

Fig. 9 SGC staff post at the new museum building at Omaira Sánchez Memorial Park in Armero-Guayabal, Colombia. New exhibits depict volcano monitoring instruments, and geology and volcanic risk of the region

activities for use in Colombian classrooms. A November 2017 trip to Colombia by three US participants explored options for a Colombian national volcano curriculum (since accomplished). In May 2017 Colombian visitors to the US observed a Nevado del Ruiz 1985 disasterinspired lahar evacuation drill of the Orting School District. In February 2018 five US participants attended Colombia's fourth biannual gathering of teachers and students for risk reduction in volcanic regions (Bienal Nacional de niños, niñas y jóvenes que viven en zonas de riesgo volcánico), and observed students demonstrate new Colombian classroom activities, some based upon US products.

\section{Helping emergency management}

During 2015 an exchange was held for staff and officials associated with Long Valley caldera in California and counterparts who addressed Chaitén Volcano in Chile (Pierson et al. 2017). The June 2016 Binational Exchange brought three Colombian representatives and USAID staff from Chile, Peru, Ecuador, Colombia, and Costa Rica to the US to observe the Cascadia Rising multistate earthquake response activity and use of the $\mathrm{Na}$ tion's incident command and National Incident Management Systems (NIMS). During April 2017, emergency managers, a state-level geologist, and a teacher visited the Nevado del Ruiz region and witnessed progress made on commemoration of the 1985 lahar disaster. In October 2018, a joint delegation of ten Ecuadorian and Colombian emergency managers attended a table-top exercise of volcano response plans for Mount Baker volcano. Mount Baker is located near the US/Canada border, and response to volcanic unrest there presents challenges similar to those posed by volcanoes near the border of Ecuador and Colombia. Lastly, a delegation of ten US emergency managers visited Ecuador in June 2019.

\section{Supporting volcano parks}

During the April 2016 trip to Colombia, participants from the US and Colombia visited Parque Nacional Natural Los Nevados and observed opportunities for creation of a UNESCO Geopark and potential interpretive opportunities. Participants also visited the Omaira Sanchez Museum. In May 2017, eight emergency managers and staff members of SGC, along with economic development, park, and museum colleagues visited the US to improve their knowledge of park-community tourism partnerships, exhibit building, and disaster memorialization efforts in support of their efforts to create a UNESCO-recognized Geopark. According to the Shimabara Declaration (UNESCO 2019), education about our dynamic planet in geoparks is a most effective way to help local communities understand how to coexist with nature which occasionally generates geohazards. Cooperation among local people, scientists, the tourism industry, municipalities and Nations is indispensable for geoheritage conservation, education, tourism, and the sustainable development of geoparks and local communities.

\section{Conclusions}

During the 2013 Binational Exchange and 6 years hence, participants collectively showed indications of 
learning within all four stages of Kolb's learning cycle. Participants in both nations are engaged in Kolb's 'active experimentation' with risk reduction measures. They are creating life-long learning opportunities with partners in schools and geoparks; are engaged in relationship building that promotes community involvement in mitigatin measures and belief in its efficacy. There is a sobering appreciation for the challenges of recovery and the need to pre-empt disaster with policy making and preparations.

Several key elements may have contributed to the 2013 Binational Exchange rising above being solely a fascinating journey abroad. A solid foundation was set because 1 ) the binational exchange fit squarely into the humanitarian mission of USAID and therefore was fundable; 2) organizers in both nations shared some familiarity and trust and recognized mutual benefits; and 3) each nation had readily identifiable hazard stories to tell and risk reduction lessons to offer.

Binational Exchange agenda organizers approached trip planning with intention. They 1) provided a pre-trip presentation about the 1985 tragedy at Nevado del Ruiz, and 'recommended readings' such as Voight (1990) and Hall et al. (1992); 2) requested that participants document the trip and their insights; 3 ) chose combinations of participants with demonstrated initiative who they perceived would work together during crises; 4) arranged a trip agenda germane to perceived or stated learning needs; 5) developed social events that promoted socialization; and 6) maintained discussions with participants concerning post-trip follow-up actions.

Participants 1) remained engaged in observations and asked insightful questions; 2) participated in intra-group discussions during the trip concerning applications back home; 3) post-trip, maintained social connections and sought ways to implement what they had learned; and 4) some participants aided the hosting of later binational exchanges, thereby reliving and reinforcing lessons learned during the 2013 experience.

Some positive feedback mechanisms further enhanced effectiveness. Post-trip interactions helped each group to maintain a sense of personal accountability regarding intentions to act. The desire to help with 'putting on a good show' during later exchanges was of itself a motivating force for mitigation. When one counts the number of people in both nations touched directly by professional involvement in the 2013 Binational Exchange, they must include dozens of emergency personnel, elected officials, park managers, educators, and the news media. This does not include the tens of thousands of people whose safety may be enhanced by participants' post-trip mitigation efforts. Several US participants contend that the visit to a different culture touched not just the intellect, but their hearts and that the trip was personally transforming.

One challenge to the legacy of a binational exchange is that professional people change jobs. Multiple members of the 2013 US delegation have transferred to other jobs or retired. The hope of all is that the momentum generated by the exchange will continue to stimulate work in volcano risk reduction.

Binational exchanges are not one-time-fix-all events but are an augmentation to training events in the homeland, including volcano-crisis trainings, emergency coordination plan development and exercising, and participation in homeland and international preparedness conferences. The binational exchange concept is transferable to other situations. Binational exchanges might have most impact when they address high-impact/low frequency events for which officials have minimal experience. Effectiveness is reinforced by post-trip continuance of relationships and sharing of memories. It is relationships that sustain memories, which in the end, can promote long-term vigilance. The 2013 Colombia-US Binational Exchange adds credence to the notion that we do not need to be passive and distant observers but can learn from the past and make improvements.

\begin{abstract}
Abbreviations
CBDRR: Community based disaster risk reduction; CVA: Centro de Visitantes de Armero; EMD: Washington Emergency Management Division;

EOC: Emergency Operations Center; FEMA: Federal Emergency Management Agency; IAVCEI: International Association of Volcanology and Chemistry of the Earth's Interior; JIC: Joint Information Center; MOC: Mobile Operations Center; NIMS: National Incident Management System; OFDA: Office of Foreign Disaster Assistance; OVSM: Vulcanological and Seismological Observatory of Manizales; SGC: Servicio Geológico Colombiano;

TORE: Thematic, organized, relevant, entertaining; UDEGER: Risk Management of Caldas Unidad Departamental de Gestión del Riesgo de Desastres; UNGRD: Unidad Nacional para la Gestión del Riesgo de Desastres; UNESCO: United Nations Educational, Scientific and Cultural Organization; USAID: US Agency for International Development; USGS: US Geological Survey; USR: Urban Search and Rescue; VDAP: Volcano Disaster Assistance Program; WCSO-DEM: Whatcom County Sheriff's Office Division of Emergency Management
\end{abstract}

\section{Authors' information}

All authors were part of the traveling groups in Colombia and the US. Any use of trade, firm, or product names is for descriptive purposes only and does not imply endorsement by the U.S. Government.

\section{Authors' contributions}

$C D$ developed and implemented the scheme for interviews, made analysis, and developed the manuscript. MC, GC, and JE researched histories. JM, AL $R A, D B, S B, H B, F B, K B, J G, Z G, F G, C G, J Q, E R$, JS, MS contributed observations and analyses. All authors read and approved the final manuscript.

\section{Funding}

This project was supported by the US Agency for International Development Office of Foreign Disaster Assistance (USAID/OFDA).

\section{Availability of data and materials}

Not applicable.

Competing interests

The authors declare that they have no competing interests. 


\section{Author details}

'US Geological Survey-Cascades Volcano Observatory, 1300 SE Cardinal Court, Vancouver, WA 98683, USA. ${ }^{2}$ SGC: Servicio Geológico Colombiano, Diagonal 53 N0. 34 - 53, Bogotá D.C., Colombia. ${ }^{3}$ OVSM: Servicio Geológico Colombiano - Observatorio Vulcanológico y Sismológico de Manizales, Avenida 12 de Octubre No. 15-47, Manizales, Caldas, Colombia. ${ }^{4}$ US Geological Survey_Volcano Disaster Assistance Program, 1300 SE Cardinal Court, Vancouver, WA 98683, USA. ${ }^{5}$ USAID, Colombia Office of US Foreign Disaster Assistance (OFDA), Oficina de los Estados Unidos de Asistencia para Desastres en el Extranjero (USAID/OFDA), Washington, D.C., USA. ${ }^{6}$ Pierce County, Economic Development Department, 950 Pacific Ave, Tacoma, WA 98402, USA. 'Washington State Department of Transportation, 310 Maple Park Avenue SE, P.O. Box 47358, Olympia, WA 98504-7300, USA. ${ }^{8}$ Mount Rainier National Park, 55210 238th Avenue East, Ashford, WA 98304, USA. ${ }^{9}$ Cruz Roja Colombiana- Seccional Tolima, Calle 38A No 5-40, Ibagué, Tolima, Colombia. ${ }^{10}$ Whatcom County Sheriff's Office Division of Emergency Management, 311 Grand Ave, Bellingham, WA 98225, USA. "11Pierce County Department of Emergency Management, 2501 S 35th St, Suite D, Tacoma, WA 98409, USA. ${ }^{12}$ Defensa Civil Colombiana - Seccional Caldas, Calle12A No 14-63, Manizales, Caldas, Colombia. ${ }^{13}$ Orting Valley Fire and Rescue, P.O. Box 386, Orting, WA 98360, USA. ${ }^{14}$ UDEGER: Unidad Departamental de Gestión de Riesgo de Desastres, Calle 22 No 20-52, Piso 4, Manizales, Caldas, Colombia. ${ }^{15}$ Secretaría de Ambiente y Gestión de Riesgo de Tolima, Calle 28 No 3-33, Ibagué, Tolima, Colombia. ${ }^{16}$ Cuerpo Oficial de Bomberos de Manizales, Calle 13A No 20-21, estación Fundadores, Manizales, Caldas, Colombia. ${ }^{17}$ Department of Homeland Security, 130 228th St SW, Bothell 98021, Wa, USA. ${ }^{18}$ LeavenworthP.O. Box 844, 98826, Wa, USA.

Received: 17 February 2019 Accepted: 5 November 2019

Published online: 27 February 2020

\section{References}

Aspinall WP, Loughlin SC, Michael FV, Miller AD, Norton GE, Rowley KC, Sparks RSJ, Young SR (2002) The Montserrat volcano observatory: its evolution, organization, role and activities. Geol Soc Lond Mem 21:71-91. https://doi. org/10.1144/GSL.MEM.2002.021.01.04

Barberi F, Davis MS, Isaia R, Nave R, Ricci T (2008) Volcanic risk perception in the Vesuvius population. J Volcanol Geotherm Res 172:244-258. https://doi.org/ 10.1016/j.jvolgeores.2007.12.011

Barclay J, Haynes K, Mitchell T, Solana C, Teeuw R, Darnell A, Crossweller HS, Cole P, Pyle D, Lowe C, Fearnley C, Kelman I (2008) Framing volcanic risk communication within disaster risk reduction: finding ways for the social and physical sciences to work together. Geol Soc Lond Spec Publ:163-177. https://doi.org/10.1144/SP305.14

Beason S, Driedger C, Lockhart A, Schelling J, Gibson Z, Burkhart, F, Banks, D, Bustad K, Allen, R, Scott M (2014) Lessons learned from a binational exchange between Colombia and the United States: Real-life emergency planning and preparedness from a worst-case scenario. In: Abstracts of the Geol Soc Amer 2014 Annual Meeting in Vancouver, British Columbia 19-22 October 2014 https://gsa.confex.com/gsa/2014AM/finalprogram/ abstract_244620.htm. Accessed 19 Sep 2019

Beason SR (2017) Change in glacial extent at Mount Rainier National Park from 1896-2015. Natural Resource Report NPS/MORA/NRR-2017/1472, National Park Service, 98 p. http://www.morageology.com/view_pub.php?id=12

Becker JS et al (2017) Organisational response to the 2007 Ruapehu Crater Lake Dam-Break Lahar in New Zealand: use of communication in creating an effective response. In: Fearnley CJ, Bird DK, Haynes K, McGuire WJ, Jolly G (eds) Observing the volcano world. Advances in volcanology (an official book series of the International Association of Volcanology and Chemistry of the Earth's Interior - IAVCEI, Barcelona, Spain). Springer. https://doi.org/10.1007/ 11157_2016_38

Bird D, Gisladottir G, Dominey-Howes D (2010) Volcanic risk and tourism in southern Iceland: implications for hazard, risk and emergency response education and training. J Volcanol Geotherm Res 18:33-48. https://doi.org/ 10.1016/j.jvolgeores.2009.09.020

Burby R, Deyle R, Godschalk D, Olshansky R (2000) Creating hazard resilient communities through land-use planning. Nat Hazards Rev 1(2):99-106 http:// ascelibrary.org/doi/pdf/10.1061/(ASCE)1527-6988(2000)1:2(99)

Cadig JR, Driedger CL, Garcia C, Duncan M, Gaillard JC, Lindsay J, Haynes K (2016) Fostering participation of local actors in volcanic disaster risk reduction. In: Fearnley CJ, Bird DK, Haynes K, McGuire WJ, Jolly G (eds) Advances in volcanology observing the volcano world: volcano crisis communication, pp 481-498 https://link.springer.com/chapter/10.1007/11157_2016_39

Cakir R, Walsh TJ (2012) Loss estimation pilot project for lahar hazards from Mount Rainier, Washington. Washington Division of Geology and Earth Resources Information Circular, p 113 http://www.dnr.wa.gov/Publications/ ger_ic113_mt_rainier_lahar_hazards.pdf

Calvache MLV (1990) Pyroclastic deposits from the November 13, 1985 eruption of Nevado del Ruiz volcano, Colombia. J Volcanol Geotherm Res 41:67-78. https://doi.org/10.1016/0377-0273(90)90083-R

Cardona O (1997) Management of the volcanic crises of Galeras volcano: social, economic and institutional aspects. J Volcanol Geotherm Res 7:313-324. https://doi.org/10.1016/S0377-0273(96)00102-3

Carlino S, Somma R, Mayberry G (2008) Volcanic risk perception of young people in the urban areas of Vesuvius - comparisons with other volcanic areas and implications. Volcanol Geotherm Res 172(3,4):229-243. https://doi.org/10. 1016/j.jvolgeores.2007.12.010

Chester DK (2005) Volcanoes, society, and culture. In: Marti J, Ernst GJ (eds) Volcanoes and the environment. Cambridge University Press, New York, pp 404-439

Cortés GP (2011) Observatorios vulcanológicos en Colombia: 25 años de vigilancia ininterrumpida. In: INGEOMINAS al dia Instituto Colombiano de Geología y Minería, pp 12-25

Crandell DR (1971) Postglacial lahars from Mount Rainier Volcano, Washington. In: US Geol Surv Professional Paper 1971, p 677 https://pubs.er.usgs.gov/ publication/pp677

Cronin S, Petterson M, Taylor P, Biliki R (2004b) Maximizing multi-stakeholder participation in government and community volcanic hazard management programs: a case study from Savo, Solomon Islands. Nat Hazards 33:105-136 http://link.springer.com/article/10.1023/B:NHAZ. 0000035021.09838 .27

Cronin SJ, Gaylord DR, Charley D, Alloway BV, Wallez S, Esau JW (2004a) Participatory methods of incorporating scientific with traditional knowledge for volcanic hazard management on Ambae Island, Vanuatu. Bull Volcanol 66:652-668 http://link.springer.com/article/10.1007/s00445-004-0347-9

Dahlstrom ME (2014) Using narratives and storytelling to communicate science with nonexpert audiences. Proc Natl Acad Sci U S A 111 (supplement 4): 13614-13620. https://doi.org/10.1073/pnas.1320645111

Dewey J (1958) Experience and nature. Dover Publications, New York, p 443

Diefenbach KA, Wood NJ, Ewert JW (2015) Variations in community exposure to lahar hazards from multiple volcanoes in Washington State (USA). J Appl Volcanol 4:4 https://appliedvolc.biomedcentral.com/articles/10.1186/s13617-015-0024-z

Donovan A, Eisner JR, Sparks RSJ (2014) Scientists' views about lay perceptions of volcanic hazard and risk. J Appl Volcanol 3:15. https:/doi.org/10.1186/s13617-014-0015-5

Donovan A, Oppenheimer C (2016) Imagining the unimaginable: communicating extreme volcanic risk. Adv Volcanol 1:15 http://link.springer.com/chapter/10.1 007/11157_2015_16

Doyle E, Paton D, Johnston D (2015) Enhancing scientific response in a crisis: evidence-based approaches from emergency management in New Zealand. J Appl Volcanol 4:1. https://doi.org/10.1186/s13617-014-0020-8

Driedger C, Calvache M, Cortés GP, Ewert JE, Lockhart AB, Montoya JA, Schelling, JD. A Colombia-US binational exchange-emergency officials sharing lessons learned to prevent future volcanic disasters. COV8 Cities on Volcanoes 8 Conference Yogyakarta, Indonesia, 9-13 September 2014

Driedger C, Doherty A, Dixon C, Faust L (2005) Living with a volcano in your backyard —an educator's guide with emphasis on Mount Rainier. (ver. 2.0, December 2014). US Geol Surv 19. https://doi.org/10.3133/gip19 General Information Product

Driedger C and Ewert JW. Volcano-hazards education for emergency officials through study trip learning - the 2013 binational exchange. Proceedings of the AGU Fall Meeting San Francisco 14-18 December 2015 https://agu. confex.com/agu/fm15/webprogram/Paper76171.html

Driedger, C, Neal, CA, Knappenberger, TH, Needham, DH, Harper RB, and Steele, WP. Hazard Information Management During the Autumn 2004 Reawakening of Mount St. Helens Volcano, Washington. In: A Volcano Rekindled: The Renewed Eruption of Mount St. Helens, 2004-2006. US Geol Surv Professional Paper 1750 Edited by: Sherrod DR, Scott WE, Stauffer PH. 2008, 505-519. https://doi.org/10.3133/pp1750

Driedger C, Scott W (2010) Media guidebook for natural hazards in Washington-addressing the threats of tsunamis and volcanoes. Edited by: Schelling J, Nelson D. Washington Military Department Emergency Management Division http://www.skagitriverhistory.com/PDFs/2010-06\%2 OSelections\%20From\%20MediaTsunamiVolcanoGuidebook.pdf 
Driedger C, Stout T, Hawk J (2002) The mountain is a volcano!_-addressing geohazards at Mount Rainier. J Assoc Nat Park Rangers 18:14-15 http:// npshistory.com/newsletters/ranger/ranger-v18n2.pdf

Driedger C, Wolfe EW, Scott KM (1998) Living with a volcano in your back yard: Mount Rainier volcanic hazards - a prepared presentation for use by public officials and educators. US Geol Surv:98-519. https://doi.org/10.3133/ ofr98519A Open-File Report

Driedger C, Scott W (2010) Media guidebook for natural hazards in Washington-addressing the threats of tsunamis and volcanoes. Edited by: Schelling J, Nelson D. Washington Military Department Emergency Management Division http://www.skagitriverhistory.com/PDFs/2010-06\%2 OSelections\%20From\%20MediaTsunamiVolcanoGuidebook.pdf

Ekse W, Burkhart F, Kloes D, Driedger C, Faust, L, Nelson, D (2015) Are you Ready for an eruption? Mount Baker and Glacier Peak interpretive sign. https:// www.dnr.wa.gov/programs-and-services/geology/geologic-hazards/ volcanoes-and-lahars\#volcano-preparedness-products

Ewert JW, Guffanti M, Murray TL. An assessment of volcanic threat and monitoring capabilities in the United States: framework for a National Volcano Early Warning System. US Geol Surv Open-File Report 2005-1164, 2005, 62 https://pubs.usgs.gov/of/2005/1164/

FEMA A whole community approach to emergency Management: Principles, themes, and pathways for action. Federal Emergency Management Agency US Department of Homeland Security Washington, DC 2011a. https://www. fema.gov/media-library-data/20130726-1813-25045-0649/whole_community_ dec2011_2_.pdf Accessed 19 Oct 2019

FEMA National Training and Education Division. Volcano Crisis Awareness AWR233, National Disaster Preparedness Training Center at the University of Hawaii, 2-day course for emergency responders 2011b. https://ndptc.hawaii. edu/training/catalog/ Accessed 30 October 2018

Fischhoff B (1995) Risk perception and communication unplugged: twenty years of process. Risk Anal 15(2):137-145. https://doi.org/10.1111/j.1539-6924.1995.tb00308.x

Fog $L$ (2015) Construcción de un plan para la apropiación social del conocimiento producido en el Servicio Geológico Colombiano:Área de Los Observatorios Vulcanológicos Y Sismológicos (OVS). Servicio Geológico Colombiano 65 https://studylib.es/doc/5662331/plan-de-acci\%C3\%B3n-parala-apropiaci\%C3\%B3n-social-del-conocimiento

Frenzen PM, Matarrese MT (2008) Managing public and media response to a reawakening volcano: lessons from the 2004 eruptive activity of Mount St. Helens. In A Volcano Rekindled: The Renewed Eruption of Mount St. Helens, 2004-2006. US Geol Surv Professional Paper 1750 Edited by: Sherrod DR, Scott WE, Stauffer PH. 2008, 493-503 https://doi.org/10.3133/pp1750

GNS Volcanoes and society: planning for a volcanic crisis in New Zealand. Short Course at Wairakei Research Centre Taupo, NZ, 7-8 October 1999

Gregg CE, Houghton BF, Johnston DM, Paton D, Swanson DA (2004) The perception of volcanic risk in Kona communities from Mauna Loa and Hualalai volcanoes, Hawai'i. J Volcanol Geotherm Res 130:179-196 https://doi. org/10.1016/S0377-0273(03)00288-9

Guffanti M, Scott W, Driedger C, Ewert J Summary of the stakeholders workshop to develop a National Volcano Early Warning System (NVEWS). US Geol Sury Open-File Report: 2006-1224, 2006 http://pubs.usgs.gov/of/2006/1224/

Hall M (1992) The 1985 Nevado del Ruiz eruption scientific, social, and governmental response and interaction before the event, Chapter 6. In: McCall G, Laming D, Scott S (eds) Geohazards—Natural and Man-Made. Chapman and Hall, London, pp 43-52. https:/doi.org/10.1007/978-94-011-2310-5_6

Ham SH (1992) Environmental interpretation: a practical guide for people with big ideas and small budgets. North American Press, Minneapolis, p 456

Ham SH (2013) Interpretation: making a difference on purpose. Fulcrum Publishing Golden, p 290

Haynes K, Barclay J, Pidgeon N (2008a) The issue of trust and its influence on risk communication during a volcanic crisis. Bull Volcanol 70:605-621. https://doi.org/10.1007/s00445-007-0156-z

Haynes K, Barclay J, Pidgeon N (2008b) Whose reality counts? Factors affecting the perception of volcanic risk. J Volcanol Geotherm Res 172(3-4):259. https://doi.org/10.1016/j.jvolgeores.2007.12.012

Hoblitt RP, Walder JS, Driedger CL, Scott KM, Pringle PT, Vallance JW (1998) Volcano hazards from Mount Rainier, Washington. US Geol Surv Open-File Report 98-428 Revised. https://doi.org/10.3133/ofr98428

Homeland Security (2008) National Incident Management System website. https:// www.fema.gov/pdf/emergency/nims/NIMS_core.pdf. Accessed on 17 Feb 2019.

IAVCEl. Understanding Volcano Hazards (1995) Internat Assoc of Volcanology and Chemistry of Earth's Interior, 20-minute video
IAVCEI. Reducing Volcanic Risk (1996) Internat Assoc of Volcanology and Chemistry of Earth's Interior, 20-minute video

Johnston D, Becker, Jl Coomer, M Ronan, K Davis, M Gregg, C (2006) Children's risk perceptions and preparedness: Mt Rainier 2006 hazard education assessment tabulated results. GNS Science Report 2006, 16 June: 30 https:// scholar.dominican.edu/all-faculty/177/

Kearney R. Narrating pain: the power of catharsis. Paragraph Jan 2008, vo. 30, No. 1:51-66. https://www.euppublishing.com/doi/pdfplus/10.3366/prg.2007.0013

Kolb D (2015) Experiential learning: experience as the source of learning and development (second edition). Pearson Education Inc, Saddle River, NJ 388

Kolb D, Boyatzis R, Mainemelis C (2001) Experiential learning theory: previous research and new directions. In: Sternberg $R$, Zhang $L$ (eds) Perspectives on cognitive learning and thinking styles. Lawrence Erlbaum Associates, Mahwah, NJ

Lane LR, Tobin GA, Whiteford LM (2003) Volcanic hazard or economic destitution: hard choices in Baños, Ecuador. Environ Haz 5(1-2):23-34 https://doi.org/10. 1016/j.hazards.2004.01.001

Lavigne F, De Coster B, Juvin N, Flohic F, Gaillard J-C, Texier P, Morin J, Sartohadi $J$ (2008) People's behavior in the face of volcanic hazards: perspectives from Javanese communities, Indonesia. J Volcanol Geotherm Res 172(3-4):273287. https://doi.org/10.1016/j.jvolgeores.2007.12.013

Maguire, Delahunt (2017) Doing a thematic analysis: A practical, step-by-step guide for learning and teaching scholars. AISHE Autumn 9:3 http://ojs.aishe. org/aishe/index.php/aishe-j/article/view/335

Marzocchi W, Newhall C, Woo (2012) The scientific management of volcanic crises. J Volcanol Geotherm Res 247-248:181-189. https://doi.org/10.1016/j. jvolgeores.2012.08.016

McGuire WJ, Solana MC, Kilburn CRJ, Sanderson D (2009) Improving communication during volcanic crises on small, vulnerable islands. J Volcanol Geotherm Res 183:63-75. https://doi.org/10.1016/j.jvolgeores. 2009.02.019

Mileti DS (1999) Disasters by design: a reassessment of natural hazards in the United States. Joseph Henry Press, Washington, D.C https://scholar.google. com/scholar?hl=en\&as_sdt=0\%2C48\&q=61.\%09Mileti+DS.+Disasters+by+ Design\%3A+A+Reassessment+of+Natural+Hazards+in+the+United+ States. $++\& b \operatorname{tnG}=$

Mileti DS, Bolton PA, Fernandez G, Updike RG (1991) The eruption of Nevado Del Ruiz volcano Colombia, South America, November 13, 1985. Commission on Engineering and Technical Systems (National Academy Press), Washington, D.C. https://scholar.google.com/scholar?hl=en\&as_sdt=0\%2C48\&q=60.\% 09Mileti+DS\%2C+Bolton+PA\%2C+Fernandez+G\%2C+Updike+RG.+The+ eruption+of+Nevado+Del+Ruiz+volcano+Colombia\%2C+South+America\%2 C+November+13\%2C+1985.+\&btnG=

Mileti DS, Sorensen JH (1990) Communication of emergency public warnings: A social science perspective and state-of-the-art assessment. Report ORNL6609. Oak Ridge National Lab, TN (US) 1990 http://www.osti.gov/scitech/ biblio/6137387-tDRffv/

Myers B Driedger CL. Eruptions in the Cascade Range during the past 4,000 years: US Geol Surv General Information Product 63 2008a, poster. doi: https://doi.org/10.3133/gip63

Myers B Driedger CL. Geologic Hazards at Volcanoes. US Geol Surv General Information Product 64 2008b, poster doi: https://doi.org/10.3133/gip64

Newhall C, Aramaki S, Barberi F, Blong R, Calvache M, Cheminee J, Punongbayan R, Siebe C, Simkin T, Sparks S, Tjetjep W (1999) Professional conduct of scientists during volcanic crises. Bull Volcanol 60:323-334. https://doi.org/10. 1007/PL00008908

Newhall CG, Punongbayan RS (1996) Fire and mud: eruptions and lahars of mount Pinatubo. University of Washington Press, Seattle http://pubs.usgs. gov/pinatubo/

Paton D, Jackson D (2002) Developing disaster management capability: an assessment Centre approach. Disaster Prev Manag 11:115-122. https://doi. org/10.1108/09653560210426795

Paton D, Johnston D, Houghton B, Flin R, Ronan K, Scott B (1999) Managing natural hazard consequences: planning for information management and decision making. J Am Soc Prof Emerg Plann, VI:37-48

Paton D, Sagala S, Okada N, Jang $\sqcup$, Burgelt PT, Gregg CE (2010) Making sense of natural hazard mitigation: personal, social and cultural influences. Environ Haz 9(2):183-196. https://doi.org/10.3763/ehaz.2010.0039

Paton D, Smith L, Daly M, Johnston D (2008) Risk perception and volcanic hazard mitigation: individual and social perspectives. J Volcanol Geotherm Res 172 : 179-188. https://doi.org/10.1016/j.jvolgeores.2007.12.026 
Peek L, Sutton J, Gump J (2008) Caring for Children in the Aftermath of Disaster: The Church of the Brethren Children's Disaster Services Program, Children, Youth and Environments. 18(1):408-421 www.jstor.org/stable/10.7721/ chilyoutenvi.18.1.0408

Perry RW, Greene MR (1983) Citizen response to volcanic eruptions: The case of Mt. St. Helens. Irvington Publishers, New York, NY https://books.google.com/ books?hl=en\&lr=\&id=N6gjcdvoDhYC\&oi=fnd\&pg=PP8\&dq=Perry, + R.W.+and + Greene,+M.R.,+1983,+Citizen+Response+to+Volcanic+Eruptions\&ots=kR2 jBSF2bd\&sig=_GqmOA31xfDjsW54MkLLT1Q-vbY\#v=onepage\&q\&f=false

Perry RW, Lindell MK (1990) Living with Mount St. Helens: Human adjustment to volcano hazards. University Press, Pullman Wash

Perry RW, Lindell MK (2008) Volcanic risk perception and adjustment in a multihazard environment. J Volcanol Geotherm Res 172:170-178. https://doi.org/ 10.1016/j.jvolgeores.2007.12.006

Perry SC, Blanpied ML, Burkett ER, Campbell NM, Carlson A, Cox DA, Driedger CL, Eisenman DP, Fox-Glassman KT, Hoffman S, Hoffman SM, Jaiswal KS, Jones LM, Luco N, Marx SM, McGowan SM, Mileti DS, Moschetti MP, Ozman D, Pastor E, Petersen MD, Porter KA, Ramsey DW, Ritchie LA, Fitzpatrick JK, Rukstales KS, Sellnow TS, Vaughon WL, Wald DJ, Wald LA, Wein A, Zarcadoolas C (2016) Get your science used-Six guidelines to improve your products. US Geol Surv Circular (1419):37. https://doi.org/10.3133/cir1419

Peters RG, Covello VT, McCallum DB (1997) Determinants of trust and credibility in environmental risk communication. Risk Anal 17(1):43-54 http:// centerforriskcommunication.org/publications/Environmental_Risk_Trust_ Credibility_Factors_Study.pdf

Peterson DW (1988) Volcanic hazards and public response. J Geophys Res 93(B5): 4161-4170 https://agupubs.onlinelibrary.wiley.com/doi/abs/10.1029/JB093 iB05p04161

Piaget J (1952) The origins of intelligence in children. International University Press, New York NY

Pierce County WA. Resilient infrastructure: planning for the next volcanic crisis in the Pacific Northwest Short Course. Meeting notes from course, Tacoma, 1920 October 2006

Pierce County WA. Mount Rainier Volcanic Hazards Plan. DEM Pierce County (Washington) Dept. of Emergency Management (working draft). 2008 http:// www.co.pierce.wa.us/index.aspx?NID=104 Accessed 2 Nov 2018

Pierson TC, Janda RJ, Thouret JC, Borrero CA (1990) Perturbation and melting of snow and ice by the 13 November 1985 eruption of Nevado del Ruiz, Colombia, and consequent mobilization, flow, and deposition of lahars. J Volcanol Geotherm Res 41:17-66. https://doi.org/10.1016/0377-0273(90)90082-Q

Pierson TC, Mangan MT, Lara LE, Amigo Á (2017) Chile-US Binational exchange for volcanic risk reduction, 2015-activities and benefits. US Geol Surv Circular 1432. https://doi.org/10.3133/cir1432

Pierson TC, Wood N, Driedger C (2014) Reducing risk from lahar hazards - concepts, case studies, and roles for scientists. J Appl Volcanol 3(16):25. https://doi.org/10.1186/s13617-014-0016-4

Pringle P Roadside Geology of Mount Rainier National Park and Vicinity, Washington Department of Natural Resources Circular 107, 2008. https://d32 ogogmya1dw8.cloudfront.net/files/sage2yc/workshops/june2017/geologic_ road_guide_mount.pdf

Ronan K, Johnston D (2005) Promoting community resilience in disasters: The role for schools, youth, and families. Springer, New York NY

Ronan K, Paton D, Johnston D, Houghton B (2000) Managing societal uncertainty in volcanic hazards--a multidisciplinary approach. Disast Prev Mgmt 9:339348. https://doi.org/10.1108/09653560010361366

Schelling J, Prado L, Driedger C, Faust L, Lovellford P, Norman D, Schroedel R, Walsh T, Westby L. Mount Rainier is an active volcano-are you ready for an eruption? Washington Department of Natural Resources, interpretive sign and website posting 2014 Accessed 2 Nov 2018. http://www.co.pierce.wa.us/index.aspx?NID=3730. Accessed 7 Feb 2019

Scott KM, Vallance JW, Pringle PT (1992) Sedimentology, Behavior, and Hazards of Debris Flows at Mount Rainier, Washington. US Geol Surv Professional Paper 1547. doi: https://doi.org/10.3133/pp1547

Siebert L, Simkin T, Kimberly P (2010) Volcanoes of the world, 3rd edn. University of California Press, Berkeley Calif

Sisson TW, Vallance JE (2009) Frequent eruptions of Mount Rainier over the last 2,600 years. Bull Volcanol 71(6):595-618. https://doi.org/10.1007/ s00445-008-0245-7

Sobelson RK, Wigington CJ, Harp V, Bronson BB (2015) A whole community approach to emergency management: strategies and best practices of seven community programs. J Emerg Manag 13(4):349-357. https://www.ncbi.nlm. nih.gov/pubmed/26312659

Thouret JC, Murcia A, Salinas R, Parra E, Cepeda H, Cantagrel JM (1990) Stratigraphy and quaternary eruptive history of the Ruiz-Tolima volcanic massif (Colombia): implications for assessment of volcanic hazards. In: Symposium international "Géodynamique andine": résumés des communications. ORSTOM, Paris, pp 391-393 (Colloques et Séminaires). Symposium International "Géodynamique Andine", Grenoble (FRA), 1990/05/ 15-17 http://www.documentation.ird.fr/hor/fdi:31077

Tilling RI (1989) Volcanic Hazards: Short Course in Geology. American Geophysical Union, Washington, D.C

UNESCO The Shimabara Declaration - European Geoparks Network 2012. http:// www.europeangeoparks.org/wp-content/uploads/2012/05/THE-SHIMABARADECLARATION.pdf Accessed 17 Feb 2019

USAID USAID History. https://www.usaid.gov/who-we-are/usaid-history. Accessed 15 Sep 2019

USGS Volcanic ash impacts \& mitigation website. https://volcanoes.usgs.gov/ volcanic_ash/. Accessed 27 Aug 2019

Vargas J. Colombia: A country under constant threat of disasters. School of Advanced Military Studies Monograph 2014-01, 66 https://pdfs. semanticscholar.org/fed9/021652bbd8bbc7251984ba8f5c906cd4a794.pdf

Vargas J (2014) Colombia: A country under constant threat of disasters. School of Advanced Military Studies Monograph 2014-01, 66 https://pdfs. semanticscholar.org/fed9/021652bbd8bbc7251984ba8f5c906cd4a794.pdf

Voight B (1990) The 1985 Nevado del Ruiz volcano catastrophe: anatomy and retrospection. J Volcanol Geotherm Res 44(3-4):349-386. https://doi.org/10. 1016/0377-0273(90)90075-Q

VolFilms films for increasing resilience to risks from volcanic hazards http:// globalvolcanomodel.org/volfilm/about-volfilm/. Accessed 25 Aug 2019

Westby L. Colombia_US Binational Exchange (2015) (Video). Retrieved from https://www.youtube.com/watch?v=MNp_7iVtd28 [English version] or https://www.youtube.com/watch?V=Xb7GSZ9Xsml [Spanish version] Accessed 2 Nov 2018

Wilson TM, Stewart C, Wardman JB, Wilson G, Johnston DM, Hill D, Hampton SJ, Villemure M, McBride S, Leonard G, Daly M, Deligne N, Roberts L (2014) Volcanic ashfall preparedness poster series: a collaborative process for reducing the vulnerability of critical infrastructure. J Appl Volcanol 3:10. https://doi.org/10.1186/s13617-014-0010-x

Wood NJ, Soulard CE (2009) Community exposure to lahar hazards from Mount Rainier, Washington. US Geol Surv Scientific Investigations Report 2009a5211 http://pubs.usgs.gov/sir/2009/5211/

Wood NJ, Soulard CE (2009a) Community exposure to lahar hazards from Mount Rainier, Washington. US Geol Surv Scientific Investigations Report 2009a5211 http://pubs.usgs.gov/sir/2009/5211/

Wood NJ, Soulard CE (2009b) Variations in population exposure and sensitivity to lahar hazards from Mount Rainier, Washington. J Volcanol Geotherm Res 188:367-378 https://appliedvolc.biomedcentral.com/ articles/10.1186/s13617-015-0024-z

Worni R, Huggel C, Stoffel M, Pulgarin B (2011) Challenges of modeling current very large lahars at Nevado del Huila Volcano, Colombia. Bull Volcanol 74(2): 309-324. https://doi.org/10.1007/s00445-011-0522-8

\section{Publisher's Note}

Springer Nature remains neutral with regard to jurisdictional claims in published maps and institutional affiliations.

Ready to submit your research? Choose BMC and benefit from:

- fast, convenient online submission

- thorough peer review by experienced researchers in your field

- rapid publication on acceptance

- support for research data, including large and complex data types

- gold Open Access which fosters wider collaboration and increased citations

- maximum visibility for your research: over $100 \mathrm{M}$ website views per year

At $\mathrm{BMC}$, research is always in progress.

Learn more biomedcentral.com/submissions 